\title{
Phylogeography of the Pacific Blueline Surgeonfish, Acanthurus nigroris, Reveals High Genetic Connectivity and a Cryptic Endemic Species in the Hawaiian Archipelago
}

\author{
Joseph D. DiBattista, ${ }^{1}$ Christie Wilcox, ${ }^{1}$ Matthew T. Craig, ${ }^{2}$ Luiz A. Rocha, ${ }^{3}$ \\ and Brian W. Bowen ${ }^{1}$ \\ ${ }^{1}$ Hawai'i Institute of Marine Biology, P.O. Box 1346, Kane'ohe, HI 96744, USA \\ ${ }^{2}$ Department of Marine Sciences, University of Puerto Rico, P.O. Box 9000, Mayagüez 00681, Puerto Rico \\ ${ }^{3}$ Marine Science Institute, University of Texas at Austin, 750 Channel View Drive, Port Aransas, TX 78373, USA
}

Correspondence should be addressed to Joseph D. DiBattista, joseph99@hawaii.edu

Received 16 June 2010; Accepted 11 October 2010

Academic Editor: Kim Selkoe

Copyright (C) 2011 Joseph D. DiBattista et al. This is an open access article distributed under the Creative Commons Attribution License, which permits unrestricted use, distribution, and reproduction in any medium, provided the original work is properly cited.

\begin{abstract}
Understanding genetic connectivity is fundamental to the design of marine protected areas in the service of ecosystem-scale management. Here we evaluate such trends for a Pacific surgeonfish (Acanthurus nigroris; $N=544$ ) at two spatial scales: (1) within the Hawaiian archipelago, and (2) across the entire species range from the central to southwest Pacific. The mtDNA cytochrome $b$ data reveal genetic divergence $(d=0.041)$ between Hawaii and the rest of the Pacific range indicating a cryptic species pair, with one taxon endemic to Hawaii. Johnston Atoll, $1400 \mathrm{~km} \mathrm{SW}$ of Hawaii, also has the Hawaiian species but is distinct from most Hawaiian locations in population genetic comparisons, indicating the limits of gene flow for this widespread reef species. No consistent population genetic differences were observed among Hawaiian sites or among the other Pacific island sites. We also detected a modest bias in gene flow from the southeast towards the northwest islands of the Hawaiian Archipelago, indicating that the Papahānaumokuākea Marine National Monument may be a recipient, rather than a source of propagules to replenish reef resources.
\end{abstract}

\section{Introduction}

Reef fishes have been subject to a number of genetic studies in the interest of understanding the dynamics of population connectivity and phylogeography [1-3]. Early molecular studies indicated that many fishes are genetically homogeneous across wide geographic scales owing to their potential for dispersal over substantial distances during the pelagic larval stages [4-7]. This traditional view has begun to shift, however, with increased genetic surveys and the advent of novel techniques (e.g., $[8,9])$. Recent research has shown population genetic structure in marine fishes on the scale of tens to a few hundred kilometers (see [10-13]), challenging the prediction of vast panmictic populations based on potential dispersal during planktonic development [14-16]. Although it is clear that larval dispersal ability remains a predictor of population structure in some cases (e.g., [17]), mounting empirical evidence suggests that other factors such as biogeographic barriers [18], contemporary oceanographic patterns [19], larval behavior [12, 20], local adaptation [21], and the ecological requirements of each species $[16,22]$ may all play greater roles in shaping population connectivity (for review, see [23]).

Contemporary population genetic structure can also be reflective of historical episodes of isolation rather than recent patterns of connectivity. Factors such as population fragmentation, extinction and recolonization, and range expansion have the potential to influence genetic signatures in reef fish that persist for many generations ([24]). One example is the rapid sea level changes driven by glaciation cycles during the Pleistocene $[25,26]$. Lowering of the sea by up to a $120 \mathrm{~m}$ below present levels during the Last Glacial 
Maximum ( $19000 \mathrm{BP}$; [27]) exposed coral reef, altered the direction of sea surface currents, and even isolated entire oceans basins (e.g., formation of the Indo-Pacific Barrier; [28]). Such periodic changes in habitat availability have the potential to alter the range of reef fish species while producing cycles of population isolation, secondary contact, and subsequent merging or speciation $[4,11]$. Repeated geological-climactic events in the Indo-West Pacific have also been invoked to explain geminate species pairs distributed in the Indian and Pacific Oceans, which display similar geographic (and genetic) boundaries [4, 18].

The study of genetic connectivity (i.e., gene flow) is particularly relevant in defining spatially explicit management regimes for reef fishes, like Marine Protected Areas (MPAs). The degree of interpopulation connectivity among geographic areas, or specific location of genetic breaks, sets the scale at which management strategies for marine species need to be applied to ensure that local extirpation is overcome by continued demographic exchange [3]. In order to promote species persistence and abundance, MPAs must be simultaneously self-sustaining and adequately linked via dispersal to other areas outside of the reserve boundaries (spillover effect; [29]). In the absence of genetic connectivity, isolated populations within a species can be identified by random changes in neutral genetic variation that accumulate over long periods of time [30].

Genetic management strategies are highly relevant to the unique ecosystems of the Pacific Islands. The Hawaiian archipelago is of particular interest given that it represents an isolated island chain and is characterized by some of the highest levels of tropical marine endemism in the world (i.e., $25 \%$ for shore fishes, [31]; $20 \%$ for molluscan fauna, [32]; $25 \%$ for algae, [33]). Endemism in other centrally located archipelagos in the Pacific is usually less than $2 \%$, with one notable exception, the Marquesas Islands (12\% for fishes; [34]). The Hawaiian Island chain, which includes both the geologically young Main Hawaiian Islands (MHI; 0.5 to 4.7 million years (my) old and the much older Northwestern Hawaiian Islands (NWHI; 7.3 to 29.8 my; [35]), extends $2600 \mathrm{~km}$ across the Central North Pacific $\left(\right.$ area $\left.=341,360 \mathrm{~km}^{2}\right)$. The MHI start from the southeastern island of Hawaii (Big Island) through all eight inhabited Windward Islands ending at Kauai. The NWHI consist of 10 uninhabited islands extending from Nihoa to Kure Atoll (see Figure 1). Despite the large size of the archipelago, individual islands lie in close proximity to each other (mean separation $150 \mathrm{~km}$ ), indicating that genetic connectivity may be high within Hawaii even with the overall isolation of the island chain (e.g., [36-39]).

The most immediate concern of marine resource managers in Hawaii is the extent of demographic linkages between the NWHI, which was declared a marine monument in June 2006 (the Papahānaumokuākea Marine National Monument) but mostly closed to fishing for decades, and the heavily fished MHI [40]. For example, if the MHI and the NWHI fish populations are connected, then stocks spanning the entire Hawaiian archipelago should be managed as a single unit. On the other hand, if NWHI populations are isolated from the MHI, management as separate units would be more appropriate. Although these islands clearly vary in terms of their level of fishing pressure, differences in oceanography and ecology further complicate the issue [40]. As one example, the NWHI are low lying atolls with modest freshwater runoff, whereas the MHI are high, mountainous islands with much greater runoff; this has the potential to influence sediment load over the surrounding coral reefs. Given that the objectives of a well-designed MPA should include fisheries enhancement [41] and the conservation of unique biodiversity [42], phylogeographic surveys assessing reef fish connectivity within the Hawaiian archipelago, as well as between Hawaii and other Pacific islands, are clearly mandated.

Here we focus on the Pacific Blueline Surgeonfish (Acanthurus nigroris), which provides an opportunity to examine the role of contemporary and historical factors in shaping present day patterns of genetic connectivity in the Pacific. A. nigroris is usually found in schools from a few to several hundred individuals and feeds primarily on plankton or filamentous algae [43]. This habitat generalist occupies lagoons, seaward reefs, mixed coral and rubble, and sand (depth range: 1 to $90 \mathrm{~m}$; [43]) across the central and western Pacific and likely lives up to 25 years [44]. This colorful fish is also not fished or targeted by the aquarium trade [45]. Longdistance dispersal in A. nigroris presumably occurs during the pelagic larval stage that lasts approximately 55 to 60 days, based on estimates from related surgeonfish [46, 47]. Despite this potential for high levels of gene flow, slight morphological differences (fin rays and gill raker counts) in this species have been detected among Pacific populations, indicating that some regions may have been isolated on an evolutionary timescale [48].

In this study, we obtained samples from across much of the known distribution of $A$. nigroris in order to assess genetic structure using mtDNA sequence data (see Figure 1). Such sampling efforts also afforded a rare opportunity to consider genetic connectivity among sites in the Pacific Ocean and thus identify putative management units. Our objective is, therefore, to address the following questions: (1) Is there evidence of genetic structure within the Hawaiian archipelago (i.e., MHI versus NWHI) that would guide ecosystem-level management? (2) Is there genetic structure among other sampled Pacific populations? and (3) Is there evidence of recent or ongoing genetic exchange across the large stretches of open ocean separating Hawaii from the rest of the Central Pacific?

\section{Methods}

2.1. Collections. A total of 544 tissue samples of A. nigroris were collected with pole spears while scuba diving or snorkeling at 20 locations across the Hawaiian Archipelago (14 sampling sites in the NWHI and MHI), Johnston Atoll, and the Central Pacific (5 sampling sites: American Samoa, Line Islands, Marshall Islands, Society Islands, and Tokelau Islands) between 2004 and 2009 (see Figure 1). Specimens collected from the uninhabited NWHI were obtained on the NOAA Ship Hi'ialakai as part of an initiative to document and monitor resources in the Papahānaumokuākea Marine 


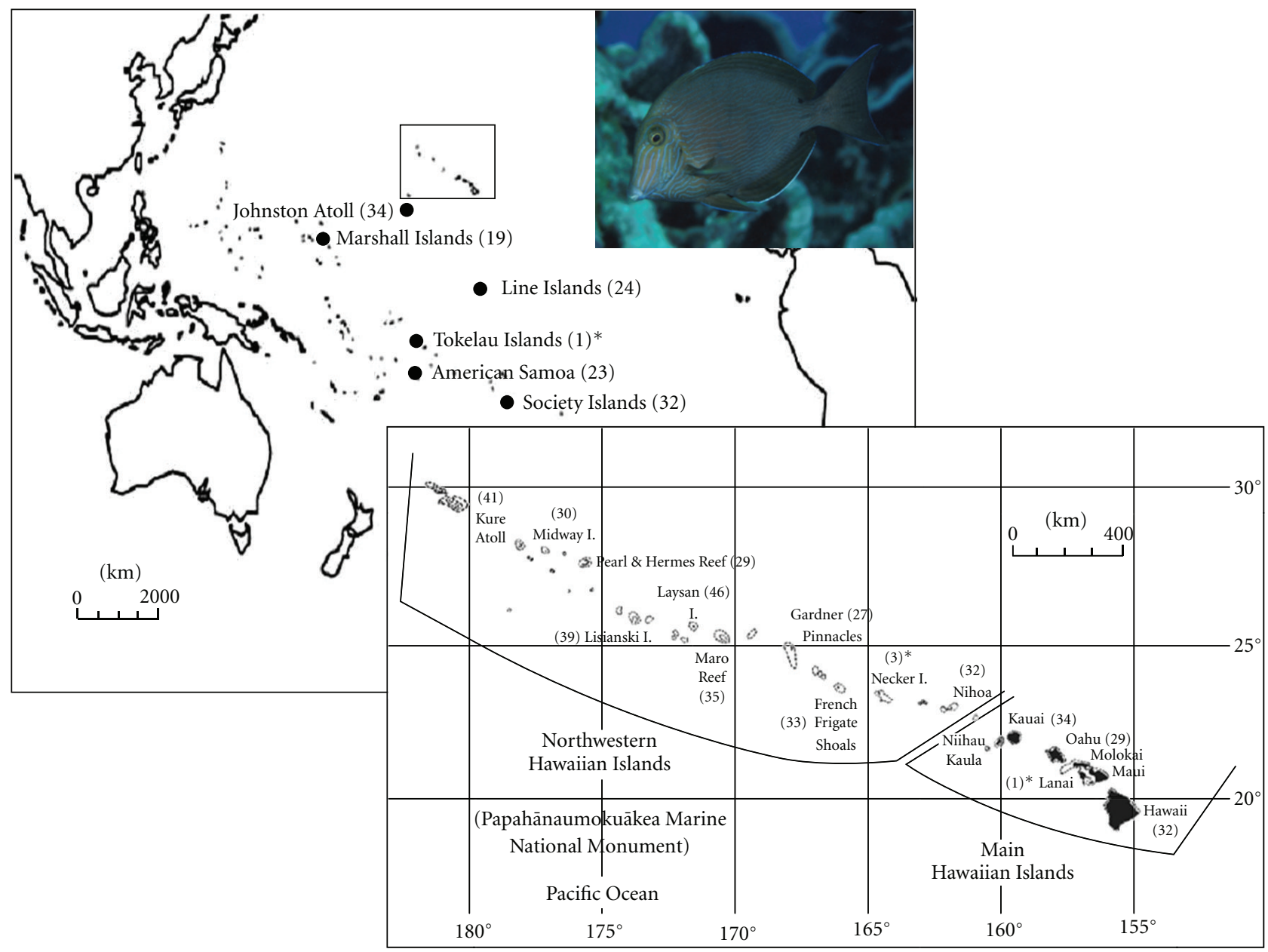

FIGURE 1: Scaled maps indicating the collection sites and sample sizes for Acanthurus nigroris in the Pacific Ocean. Locations marked with an asterisk were omitted from most population genetic analyses owing to low sample sizes (i.e., $N<6$ in all cases) but were included when all (or only "Pacific") populations were pooled together, as well as in subsequent statistical parsimony networks. Map of the Hawaiian archipelago is courtesy of NOAA. Note that the boundaries of the Papahānaumokuākea Marine National Monument include only the Northwestern Hawaiian Islands (Photo credit: Jack Randall).

National Monument; all other samples were obtained during research expeditions by authors and colleagues. Tissue was stored in $70 \%$ ethanol or in a saturated salt-DMSO buffer at room temperature $\left(25^{\circ} \mathrm{C}\right)$ until DNA extraction.

2.2. DNA Extraction, PCR, and Sequencing. Total genomic DNA was extracted from each tissue sample using a "HotSHOT" protocol [49] and subsequently stored at $-20^{\circ} \mathrm{C}$. A 797 base pair (bp) segment of the mtDNA cytochrome $b$ (cyt $b$ ) gene was amplified using heavy-strand (5'-GTGACTTGAAAAACCACCGTTG-3'; [50]) and light-strand primers (5'-AATAGGAAGTATCATTCGGGTTTGATG-3'; [51]). Polymerase chain reaction (PCR) mixes were prepared following manufacturer's instructions using BioMixRED (Bioline Ltd., London, UK), $0.26 \mu \mathrm{M}$ of each primer, and 5$50 \mathrm{ng}$ template DNA in $15 \mu \mathrm{l}$ total volume. Thermal cycling reactions used the following parameters: initial denaturing step at $95^{\circ} \mathrm{C}$ for 10 minutes, then 35 cycles of amplification (30 seconds of denaturing at $94^{\circ} \mathrm{C}, 45$ seconds of annealing at $63^{\circ} \mathrm{C}$, and 45 seconds of extension at $72^{\circ} \mathrm{C}$ ), followed by a final extension at $72^{\circ} \mathrm{C}$ for $10 \mathrm{~min}$.

PCR products were cleaned of excess oligonucleotides and unincorporated primers by incubating with exonuclease I and shrimp alkaline phosphatase (ExoSAP; USB, Cleveland, $\mathrm{OH}$, USA) at $37^{\circ} \mathrm{C}$ for $60 \mathrm{~min}$, followed by deactivation at $85^{\circ} \mathrm{C}$ for $15 \mathrm{~min}$. All samples were then sequenced in the forward direction (and reverse direction for rare or questionable haplotypes, $N=3$ ) with fluorescently labeled dye terminators following manufacturer's protocols (BigDye, Applied Biosystems Inc., Foster City, CA, USA) and analyzed using an ABI 3130XL Genetic Analyzer (Applied Biosystems) at the Hawaii Institute of Marine Biology EPSCoR Sequencing Facility. The sequences were aligned, edited, and trimmed to a common length using Geneious Pro vers. 4.8.4 DNA analysis software [52]. Variable sites were visually checked to ensure accuracy, and unique mtDNA cyt $b$ haplotypes were deposited in GenBank (accession numbers: HM242298 to HM242393). jModelTest vers. 1.0.1 ([53]; but also see [54]) 
was used to determine the best nucleotide substitution model under Akaike information criterion $(A I C)$; the Tamura-Nei model [55], with no gamma parameter, was here selected.

\subsection{Population Genetic Analyses. ARLEQUIN vers. 3.1 soft-} ware [56] was used to calculate haplotype $(h)$ and nucleotide diversity $(\pi)$ for cyt $b$ sequences (as per [57]), as well as to test for genetic connectivity on several geographic scales: (1) within the Hawaiian archipelago, (2) among all other Central Pacific island groups (hereafter denoted "Pacific"), and (3) between Hawaiian and Pacific populations considered here. To test for genetic partitioning between regions, among populations within regions, and between all populations, we used Analysis of Molecular Variance (AMOVA; [58]); nonparametric permutation procedures $(N=99999$ iterations) were used to construct null distributions and test the significance of variance components for each hierarchical comparison. Population pairwise $\Phi_{\mathrm{ST}}$ statistics (a molecular analog of $F_{\mathrm{ST}}$ that includes information on mitochondrial haplotype frequency and genetic distance) were generated to identify genetic partitioning; significance was tested by permutation and $P$ values adjusted according to the modified false discovery rate method (as per [59]). Genetic structure was also assessed with methods that do not make $a$ priori assumptions about group identity (Spatial Analysis of Molecular Variance, SAMOVA 1.0; [60]) in order to confirm genetic patterns apparent with AMOVA. SAMOVA mitigates bias in group designation by implementing a simulated annealing process $(N=100$ permutations) to randomly partitioned mtDNA sequences into $K$ groups. We tested $K=$ 2 to $K=20$, and the configuration with the largest among group differentiation $\left(\Phi_{\mathrm{CT}}\right)$ was retained. Moreover, pairwise genetic differences between populations (or regions) were calculated by dividing the average number of corrected nucleotides that differ between samples (as per [55]) by the total number of base pairs in that sequence (i.e., corrected sequence divergence, $d$ ).

Deviations from neutrality were assessed with Tajima's $D$ [61] and Fu's Fs [62] for each population using ARLEQUIN; significance was tested with 99999 permutations. Negative (and significant) Tajima's $D$ and Fu's $F$ s values indicate an abundance of rare haplotypes or recent mutations in nonrecombining sequences such as mtDNA, a signature of population expansion or background selection. As neutrality tests are sensitive to deviations from panmixia, we estimated these statistics both on the full data set and independently within each region identified as genetically distinct by SAMOVA (i.e., all Hawaiian Islands including Johnston Atoll versus all other Pacific islands). Samples collected from Johnston Atoll were initially grouped with Hawaiian samples given the pronounced overlap of inshore fish fauna between these two regions [63]. Moreover, three sites had low sample sizes (Necker Island, $N=3$; Lanai, $N=1$; Tokelau Islands, $N=1$ ) and were, therefore, omitted from most population genetic analyses, although these specimens were included in parsimony networks and when all populations (or exclusively Hawaiian or Pacific populations) were pooled together.

Evolutionary relationships were estimated by constructing unrooted parsimony-based haplotype networks with the program NETWORK vers. 4.5.1.0 (http://www.fluxusengineering.com/network_terms.htm). The haplotype network was generated using a median joining algorithm and default settings (as per [64]), and each haplotype divided into representative populations as reflected by the pie diagrams.

2.4. Coalescence Analyses. The historical demography of $A$. nigroris was analyzed by calculating mismatch distributions (the distribution of observed differences between haplotypes; [65]) and Harpending's raggedness index [66] with $A R L E Q U I N$. We estimated such metrics for cyt $b$ sequences from four different datasets: (1) all MHI populations $(N=$ 92 individuals), (2) all NWHI populations $(N=315$ individuals), (3) the entire Hawaiian archipelago (including Johnston Atoll, $N=441$ individuals), and (4) all remaining Pacific populations ( $N=98$ individuals, excluding Tokelau). Populations that have been stable over time exhibit bimodal or multimodal mismatch distributions, whereas unimodal distributions or nonsignificant raggedness scores suggest recent (and rapid) population expansion (see [65]). All four datasets were also fitted with the population parameter $\tau$ in order to estimate the time to coalescence (as per $[66,67]$ ). Time to coalescence (or population age) was calculated using the equation $\tau=2 \mu t$, where $t$ is the age of the population in generations and $\mu$ is the mutation rate per generation for the sequence ( $\mu=$ number of base pairs - divergence rate within a lineage - generation time in years). A range of mutation rate estimates were taken from previous work in fish (1\% to $2 \%$, based on $2 \%$ per million years between lineages or $1 \%$ within lineages, [5]; 1.55\% per million years within lineages or $1.55 \times 10^{-8}$ mutations per site per year, [68]), and while generation time is unknown for A. nigroris, we conditionally used 5 years based on estimates in a related surgeonfish (Acanthurus nigrofuscus, [44]). Although absolute values of time to coalescence should be interpreted with caution here owing to the approximation of mutation rate and generation time, comparisons between populations within this dataset provide useful estimates of within-species variation.

To further explore genetic connectivity of $A$. nigroris within the Pacific Ocean, we estimated coalescence-based migration rates $(N m$, where $N$ is the effective female population size and $m$ is migration rate) with the program MIGRATE vers. 3.1.2 [69]. Estimates of gene flow generated in MIGRATE are not constrained by the assumption that a single ancestral population has split into two daughter populations [70] and appear to be robust to some common biases [71]. Although these approaches are sometimes sensitive to the presence of unsampled (i.e., ghost) populations [72], collecting A. nigroris from almost all of the Hawaiian islands as well as pooling the remaining Pacific samples for analysis likely reduced these effects. MIGRATE was therefore run: (1) among the MHI ( $N=92$ individuals), NWHI $(N=278$ individuals $)$, and Johnston Atoll $(N=34$ individuals), (2) among all remaining Pacific populations ( $N=98$ individuals), and (3) between Hawaiian and Pacific populations by pooling all sampled individuals from each region (Hawaii, including Johnston Atoll, $N=445$; Central Pacific, $N=99$ ). 
Estimates of migration rates based on coalescence theory provide not only an indication of the level of migration and population size, but also the directionality of gene flow in most cases. The maximum-likelihood (ML) approach implemented in MIGRATE, however, can sometimes provide unrealistic migration rate estimates and inflated confidence intervals (see [71, 73]). We therefore employed the recommended Bayesian inference search strategy of a single, replicated, 500,000 step chain with the first 20\% discarded as burn in [74]. Each run was replicated ten times to ensure that the parameter space was widely sampled, and we took the average of all runs to calculate migration rates, thus accounting for variability between runs. Starting parameters for $\theta$ (theta) and $M$ were estimated from $F_{\text {ST }}$ [75], and initial runs were conducted with default exponential priors and an unrestricted migration model; posterior distributions for $\theta$ and $M$ were used to inform priors for the final set of replicated runs. Only runs that produced normally distributed, unimodal posterior $\theta$ distributions were considered here.

Estimates of the number of migrants per generation were calculated by multiplying final estimates (mean $2.5 \%$, and $97.5 \%$ quantile) of $\theta$ and $M$ [76]. Given that we employed a single locus and make a number of simplifying assumptions regarding population history, we also regard these estimates as informative primarily for comparisons among populations within this dataset; comparisons with other species should be conducted with caution.

\section{Results}

3.1. Molecular Characteristics. We resolved $797 \mathrm{bp}$ of mtDNA (cyt $b$ ) from 544 A. nigroris sampled at 20 locations across the Pacific Ocean (see Figure 1 and Table 1). There were no shared haplotypes between Hawaiian populations (including Johnston Atoll) and the remaining Pacific islands. In the Hawaiian samples, we observed 38 haplotypes (35 transitions, 1 transversion, and no indels). The most common and second most common haplotypes were detected at every site, and overall, the number of unique haplotypes per site was low. In the remaining Pacific islands, 58 haplotypes were observed (66 transitions, 3 transversion, and no indels), and while there were multiple haplotypes common to many of the sites, the majority of haplotypes were observed exclusively at single locations. Indeed, haplotype diversity was twice as high and nucleotide diversity almost an order of magnitude higher within Pacific sites $(h=0.97, \pi=0.0061)$ compared to Hawaiian sites ( $h=0.52, \pi=0.00080$; Table 1 ), despite a much greater sampling effort in the latter $(N=441$ in Hawaii versus $N=98$ in the Pacific). Note that the three sites that had low sample sizes (Necker Island, $N=3$; Lanai, $N=1$; Tokelau Islands, $N=1$ ) shared common haplotypes with either Hawaiian or Pacific samples, thus justifying their inclusion in pooled analyses.

Negative and significant Tajima's $D$ (or Fu's Fs) values in 7 out of the 13 (or 9 out of 13) Hawaiian samples (Tajima's $D=-1.99$ to -0.46 ; Fu's $F s=-7.018$ to -0.73 ) and in 3 out of the 4 (or 4 out of 4 ) remaining Pacific samples (Tajima's $D=-1.64$ to -1.31 ; Fu's $F s=-17.76$ to -7.54 ; Table 1) indicate past population expansion or selection within each region. These results were similar when both the Hawaiian and Pacific regions were analyzed separately (data not shown), indicating that our neutrality statistic estimates were robust to deviations from panmixia (see below).

3.2. Population Genetic Analyses. Grouping samples into Hawaiian (including Johnston Atoll) and the remaining Pacific locations with AMOVA revealed that most of the variability in mtDNA was explained by a significant break between these two regions $\left(\Phi_{\mathrm{CT}}=0.96, P<0.001\right.$; see Table 2). Moreover, variance explained by the amongpopulations-within-regions variance component $\left(\Phi_{\mathrm{SC}}=\right.$ $0.014, P=0.035$ ) was an order of magnitude smaller than that between regions. This pattern held even when Johnston Atoll was excluded from AMOVA analysis altogether $\left(\Phi_{\mathrm{CT}}=\right.$ $0.96, P<0.001 ; \Phi_{\mathrm{SC}}=0.010, P=0.088 ; \Phi_{\mathrm{ST}}=0.96, P<$ 0.001 ), and so the overall patterns were therefore not driven by its inclusion in the Hawaiian group. SAMOVA further confirms these genetic partitions (i.e., $K=2$ maximally differentiated groupings) with all Hawaiian populations (including Johnston Atoll) being significantly different from the remaining Pacific populations $\left(\Phi_{\mathrm{CT}}=0.96, P<0.001\right)$.

Population pairwise tests provide insight into particular geographic regions or sites, where genetic partitioning is considerable, modest, or absent (Table 3). We found no significant genetic differentiation among sites within the Pacific (pairwise $\Phi_{\mathrm{ST}}$ range: -0.0063 to 0.027 ), but comparisons among sampling locations in the Hawaiian archipelago revealed some genetic structure (pairwise $\Phi_{\mathrm{ST}}$ range: -0.0015 to 0.19). Samples from Johnston Atoll were significantly different from all other Hawaiian locations except for French Frigate Shoals $(P=0.043)$, Kauai $(P=$ $0.049)$, and Kure $(P=0.24)$. Removal of Johnston Atoll from the analysis eliminated significant (albeit marginal) genetic structuring within the Hawaiian archipelago (AMOVA with Johnston Atoll: $\Phi_{\mathrm{ST}}=0.019, P=0.011$; AMOVA without Johnston Atoll: $\Phi_{\mathrm{ST}}=0.011, P=0.073$ ).

A haplotype network based on statistical parsimony supports the genetic (and geographic) partitioning of $A$. nigroris into two clusters corresponding to the Hawaiian archipelago (including Johnston Atoll) and the remaining Pacific sampling sites (Figure 2). The characteristic "star phylogeny" for the two dominant Hawaiian haplotypes is consistent with low partitioning among samples [77], as well as a more recent population expansion of A. nigroris within Hawaii. Numerous low frequency haplotypes, on the other hand, were observed for the Pacific populations. We also found that the average corrected sequence divergence between Hawaiian and Pacific haplotypes was large $(d=$ $4.12 \%$, based on 25 mutational steps), consistent with a long period of separation between the two lineages. Genetic divergence within each region, on the other hand, was much lower (Hawaii, average $d=0.10 \%$; Pacific, $d=0.60 \%$ ).

3.3. Coalescence Analyses. In order to resolve the relative timing of A. nigroris lineage divergence between Hawaii and the rest of the Pacific, as well as to infer putative population expansion events, we estimated pairwise mismatch distributions and coalescence times for individuals from: 
TABLE 1: Sample size and molecular diversity indices for the studied Acanthurus nigroris.

\begin{tabular}{|c|c|c|c|c|c|c|c|}
\hline Collection locality & $N$ & $H_{N}$ & $H_{U}$ & Haplotype diversity $(h \pm \mathrm{SD})$ & Nucleotide diversity $(\pi \pm \mathrm{SD})$ & Tajima's $D$ & Fu's Fs \\
\hline \multicolumn{8}{|l|}{ Hawaiian Archipelago } \\
\hline French Frigate Shoals & 33 & 6 & 1 & $0.42 \pm 0.10$ & $0.00064 \pm 0.00062$ & $-1.57^{\mathrm{a}}$ & -3.74 \\
\hline Gardner Pinnacles & 27 & 4 & 0 & $0.57 \pm 0.061$ & $0.00080 \pm 0.00072$ & -0.46 & -0.76 \\
\hline Hawaii (i.e., Big Island) & 32 & 10 & 3 & $0.66 \pm 0.085$ & $0.0012 \pm 0.00094$ & -1.93 & -7.018 \\
\hline Johnston Atoll & 34 & 4 & 1 & $0.22 \pm 0.093$ & $0.00037 \pm 0.00044$ & -1.75 & -2.37 \\
\hline Kauai & 34 & 3 & 1 & $0.27 \pm 0.092$ & $0.00040 \pm 0.00047$ & -0.69 & -0.73 \\
\hline Kure Atoll & 41 & 6 & 1 & $0.31 \pm 0.093$ & $0.00054 \pm 0.00056$ & -1.84 & -4.059 \\
\hline Laysan Island & 46 & 9 & 5 & $0.58 \pm 0.069$ & $0.00086 \pm 0.00074$ & -1.74 & -6.43 \\
\hline Lisianski Island & 39 & 8 & 3 & $0.58 \pm 0.082$ & $0.0010 \pm 0.00083$ & -1.99 & -4.45 \\
\hline Maro Reef & 35 & 7 & 2 & $0.62 \pm 0.064$ & $0.00095 \pm 0.00080$ & -1.34 & -3.57 \\
\hline Midway Island & 30 & 6 & 3 & $0.58 \pm 0.080$ & $0.00097 \pm 0.00081$ & -1.41 & -2.47 \\
\hline Nihoa & 32 & 9 & 4 & $0.63 \pm 0.091$ & $0.00086 \pm 0.00075$ & -1.97 & -7.35 \\
\hline Oahu & 29 & 5 & 1 & $0.54 \pm 0.093$ & $0.00082 \pm 0.00073$ & -0.94 & -1.81 \\
\hline Pearl and Hermes Reef & 29 & 5 & 0 & $0.64 \pm 0.057$ & $0.00096 \pm 0.00081$ & -0.66 & -1.39 \\
\hline All of Hawaii ${ }^{\mathrm{b}}$ & 441 & 38 & 25 & $0.52 \pm 0.025$ & $0.00080 \pm 0.00069$ & -2.38 & $-3.4 \times 10^{38}$ \\
\hline \multicolumn{8}{|l|}{ Pacific } \\
\hline American Samoa & 23 & 16 & 7 & $0.94 \pm 0.034$ & $0.0054 \pm 0.0031$ & -1.61 & -7.95 \\
\hline Line Islands & 24 & 16 & 10 & $0.95 \pm 0.029$ & $0.0053 \pm 0.0031$ & -1.31 & -7.54 \\
\hline Marshall Islands & 19 & 19 & 15 & $1.00 \pm 0.017$ & $0.0065 \pm 0.0037$ & -1.64 & -17.76 \\
\hline Society Islands & 32 & 25 & 15 & $0.98 \pm 0.012$ & $0.0073 \pm 0.0040$ & -1.53 & -16.56 \\
\hline All of Pacific ${ }^{\mathrm{b}}$ & 98 & 58 & 47 & $0.97 \pm 0.0081$ & $0.0061 \pm 0.0033$ & -2.069 & -25.54 \\
\hline
\end{tabular}

Abbreviations are as follows: $N$ : sample size; $H_{N}$ : number of haplotypes; $H_{U}$ : number of unique haplotypes.

a Numbers in bold are significant, $P<0.05$.

${ }^{\mathrm{b}}$ Samples from Necker Island $(N=3)$, Lanai $(N=1)$, and the Tokelau Islands $(N=1)$ were omitted from these analyses.

TABle 2: Genetic structuring (Analysis of Molecular Variance, AMOVA) of Acanthurus nigroris sampled at sites throughout the Pacific based on 797 bp of mtDNA cyt $b$ sequence data $(N=539)$. All Hawaiian populations (including Johnston Atoll) and the remaining Pacific populations were divided into two separate groups to assess the relationship between these regions. $\Phi_{\mathrm{CT}}$ : region variance component relative to total variance; $\Phi_{\mathrm{SC}}$ : between population within region variance component divided by the sum of itself and within population variance; $\Phi_{\mathrm{ST}}$ : sum of the variance due to region and population within region divided by the total variance.

\begin{tabular}{|c|c|c|c|c|c|c|c|c|}
\hline Source & d.f. & SS & $\begin{array}{c}\text { Variance } \\
\text { components }\end{array}$ & $\begin{array}{c}\% \\
\text { variation }\end{array}$ & $\begin{array}{l}\Phi_{\mathrm{CT}} \\
\Phi_{\mathrm{SC}}\end{array}$ & $P$ value & $\Phi_{\mathrm{ST}}$ & $P$ value \\
\hline $\begin{array}{l}\text { Among regions } \\
\text { (Hawaii versus Pacific) }\end{array}$ & 1 & 2543.54 & 15.86 & 95.74 & $0.96^{\mathrm{a}}$ & $<0.001$ & 0.96 & $<0.001$ \\
\hline $\begin{array}{l}\text { Among populations } \\
\text { (within regions) }\end{array}$ & 15 & 15.11 & 0.0097 & 0.06 & 0.014 & 0.035 & & \\
\hline Within populations & 522 & 363.35 & 0.70 & 4.2 & & & & \\
\hline
\end{tabular}

${ }^{a}$ Numbers in bold are significant, $P<0.05$.

(1) all MHI populations, (2) all NWHI populations, (3) the entire Hawaiian archipelago (including Johnston Atoll), and (4) the remaining Pacific populations (Figure 3). For all MHI populations, the unimodal mismatch distribution did not show a significant deviation from the simulated sudden demographic expansion null model (Harpending's raggedness index, $r=0.11, P=0.35$, Figure $3 \mathrm{a}$ ); all other datasets, on the other hand, deviated from such a model despite being unimodally distributed (NWHI: Harpending's raggedness index, $r=0.12, P=0.005$, Figure $3 \mathrm{~b}$ ); Hawaiian archipelago: Harpending's raggedness index, $r=0.11, P=$ 0.016 , Figure 3c; Pacific: Harpending's raggedness index, $r=$
0.026, $P=0.004$, Figure $3 \mathrm{~d})$. Using the range of mutation rates (see Methods) and the population parameter $\tau$, we identified markedly different coalescence dates in Hawaiian and Pacific populations (MHI: 20,953 to 41,905 years, $\tau=$ 0.67; NWHI: 23,771 to 47,541 years, $\tau=0.76$; Hawaiian archipelago: 22,178 to 44,356 years, $\tau=0.71$; Pacific: 163,210 to 326,419 years, $\tau=5.20$ ). Notably the coalescent estimates here reflect only the most recent population expansion in each region and not separation times between Hawaiian and Pacific A. nigroris (see above).

Our population genetic analyses were further supported by estimates of bidirectional, effective migration rates $(\mathrm{Nm})$ 


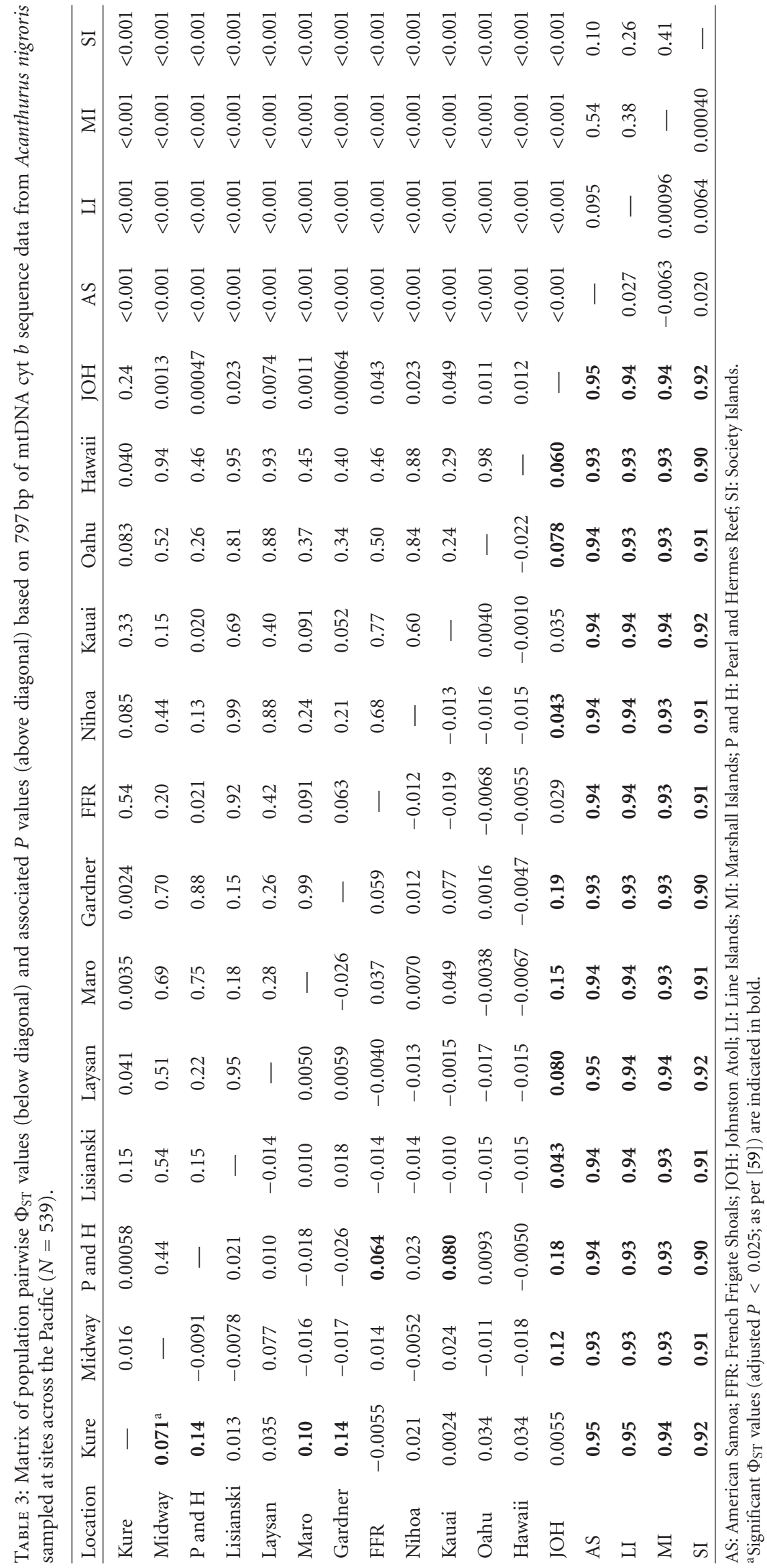




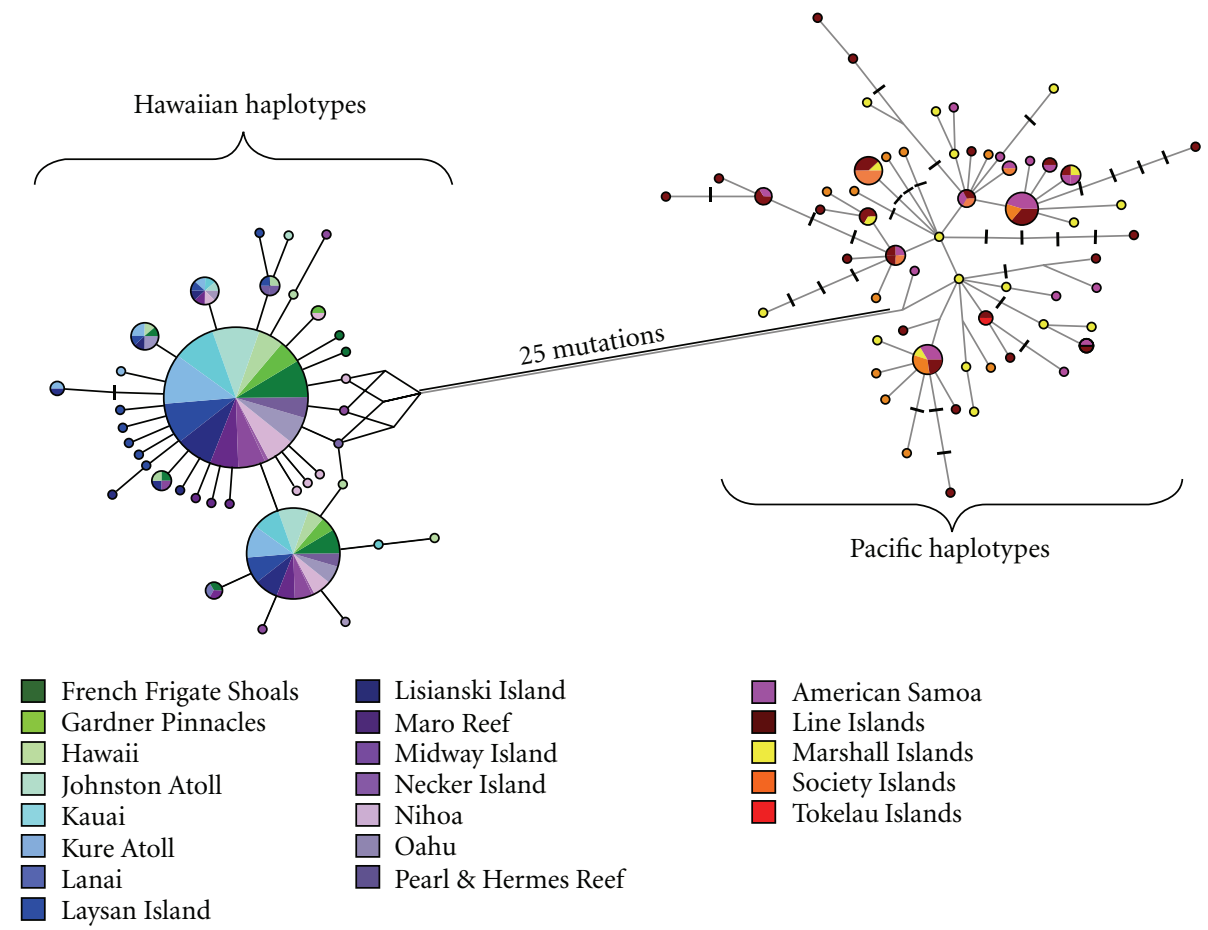

FIGURE 2: Median-joining statistical parsimony network based on 797 bp of mitochondrial cyt $b$ sequence data $(N=544)$ from Acanthurus nigroris sampled across the Pacific. Each circle represents a haplotype, and its size is proportional to its total frequency. Branches represent a single nucleotide change and black crossbars indicate unsampled haplotypes; colors denote collection location as indicated by the embedded key. It should be noted that there were no shared haplotypes between Hawaiian (including Johnston Atoll) and the remaining Pacific populations, which form two distinct clades separated by 25 mutational steps (corrected sequence divergence, $d=4.12 \%$; [55]).

with Bayesian methods. Migration was by far the greatest within the Pacific and Hawaiian regions and not surprisingly low between regions (Table 4). Indeed, based on a genetic distance of 25 mutational steps, the number of estimated migrants from the Hawaiian archipelago to the rest of the Pacific (and vice versa) approaches zero. Within Hawaii in particular, there was a modest bias in migration from the MHI to the NWHI $(\mathrm{Nm}=35.19,95 \% \mathrm{CI}=0-162)$ versus from the NWHI to the MHI $(\mathrm{Nm}=22.99,95 \% \mathrm{CI}=$ $0-132)$. Moreover, the number of migrants per generation moving from Hawaii to Johnston Atoll (from MHI: $\mathrm{Nm}=$ 3.69, $95 \%$ CI $=0-26.01$; from NWHI: $N m=3.22$, $95 \%$ CI $=0-24.65)$ was more than an order of magnitude lower than migration from Johnston to Hawaii (to MHI: $N m=62.11,95 \% \mathrm{CI}=4.79-197$; to NWHI: $N m=62.56$, $95 \%$ CI $=3.83-190$ ), indicating that gene flow is biased towards rather than away from the Hawaiian archipelago. The posterior distributions for all parameters were also consistent over multiple runs, thus indicating sufficient convergence to interpret values [78].

\section{Discussion}

All genetic analyses outlined above support the conclusion that Hawaiian A. nigroris represents an ancient evolutionary separation from those sampled elsewhere in the Pacific Ocean. Genetic distance among these distinct groups is comparable to or greater than comparisons among other congeneric pairs of reef fishes [79-82], which indicates independence between regions. On the other hand, we found that with few exceptions, there were high levels of genetic connectivity within Hawaii as well as among all other sampled Pacific island populations. Johnston Atoll also has a significant population genetic distinction from many, but not all Hawaiian samples (see Table 3), with implications for the colonization of Hawaiian reefs.

4.1. Gene Flow in Hawaii. One objective in this study was to characterize genetic structure within the Hawaiian archipelago $(2600 \mathrm{~km}$ from Kure Atoll to the island of Hawaii); throughout this region, we found little evidence for population genetic differentiation of A. nigroris. The existence of haplotypes shared across vast distances in Hawaii indicates that populations from each of these separate islands either freely exchange propagules or have done so in the recent past.

We are particularly interested in whether fish sampled in the MHI are connected to those in the NWHI, the largest marine conservation area under US jurisdiction. Based on our genetic results here, we cannot exclude this possibility. Although the short-term success of the NWHI monument in protecting regional biodiversity depends on enforcement within the reserve itself, long-term persistence of these reef fish populations also requires connectivity with other sites. The high genetic connectivity of A. nigroris detected within the Hawaiian archipelago indicates that movement of 


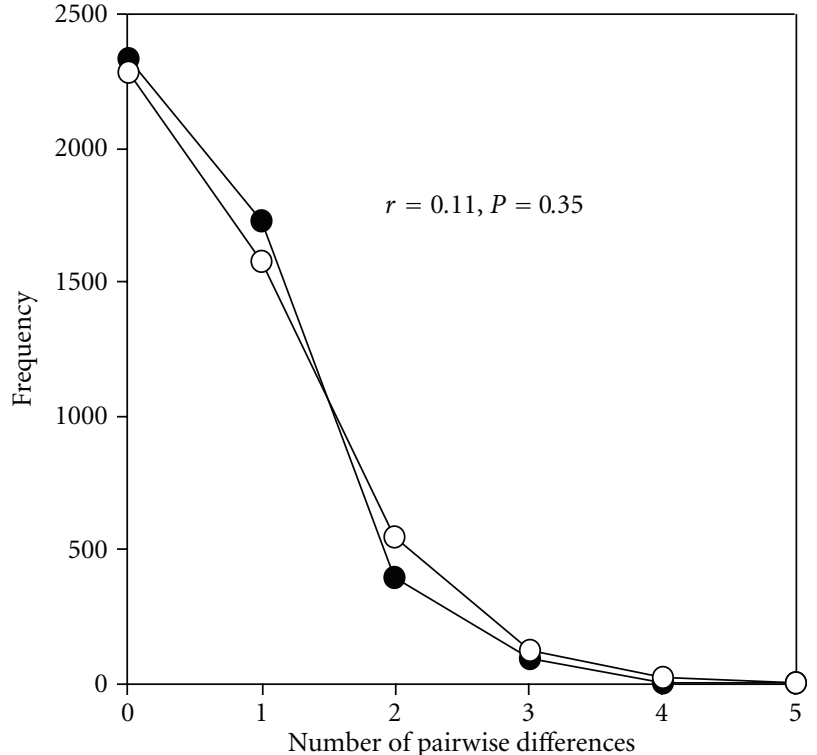

(a)

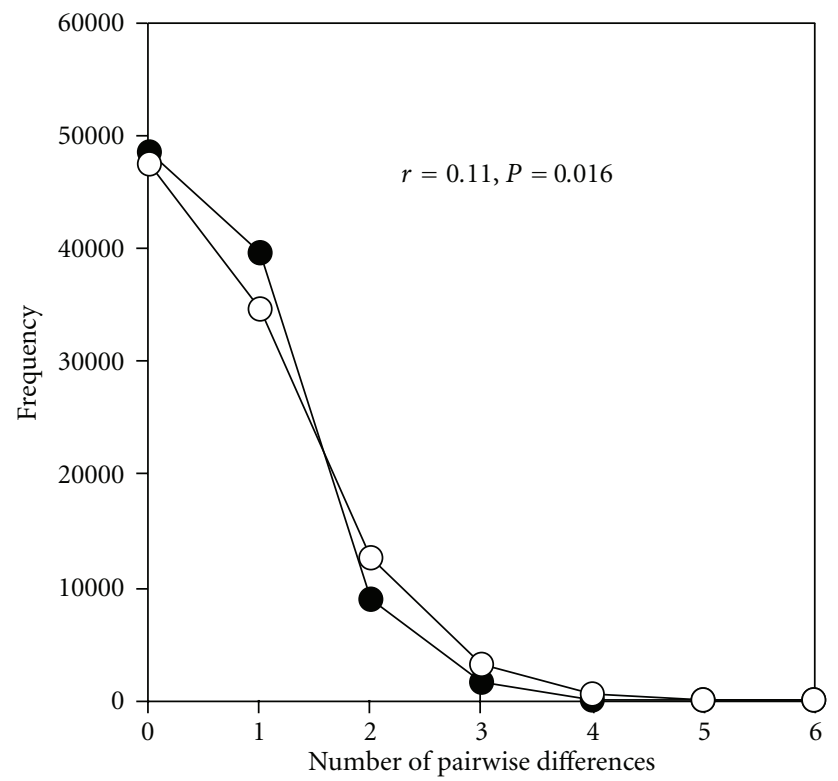

(c)

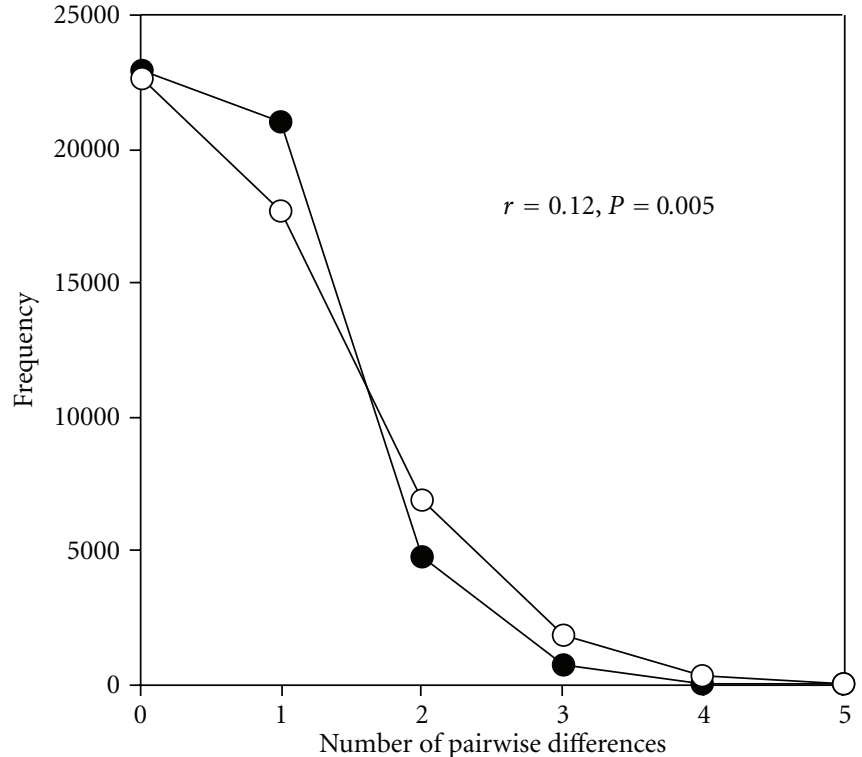

(b)

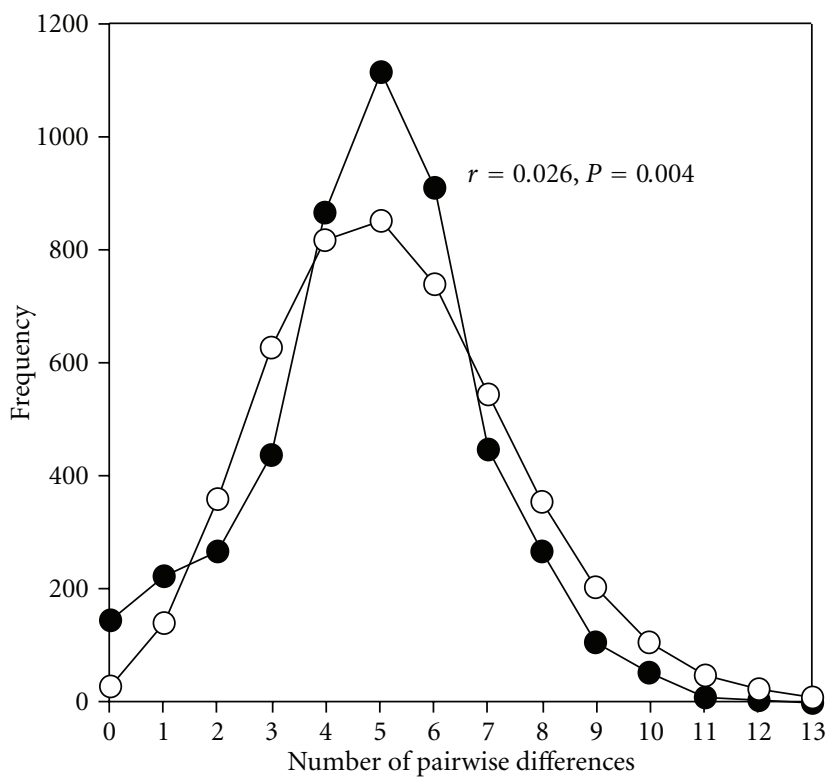

(d)

FIGURE 3: Mismatch distributions of mitochondrial cyt $b$ sequence data from Acanthurus nigroris from (a) all Main Hawaiian Island (MHI) populations ( $N=92$ individuals), (b) all Northwest Hawaiian Island (NWHI) populations ( $N=315$ individuals), (c) the entire Hawaiian archipelago (including Johnston Atoll, $N=441$ individuals), and (d) all remaining Pacific populations $(N=98$ individuals). Observed and simulated pairwise differences calculated in ARLEQUIN vers. 3.1 are represented by lines drawn through black and open circles, respectively. Harpending's raggedness index $(r)$ and associated $P$ values are shown for each dataset.

fish larvae from the NWHI may supply adjacent fisheries, although high exploitation rates in the MHI could erode any such beneficial effects. High human population density, along with the immediate effects of urbanization (i.e., increased sediment, nutrients, and pollutants) and unregulated fishing, have depleted MHI fish fauna [40, 83]. Total fish biomass of large apex predators, a common indicator of healthy coral reef ecosystems, is also more than an order of magnitude higher in the uninhabited NWHI [40], as well as elsewhere in the Pacific [83-85].
If the lack of genetic structure observed throughout the Hawaiian archipelago is the result of life-history traits that differentially affect larval dispersal in reef fishes, comparisons among published genetic surveys might help resolve why some species appear to exchange propagules over long distances and others do not (Table 5). Here we show that 6 out of the 14 species surveyed throughout Hawaii display clear genetic breaks between sites in the NWHI versus MHI, but that there is no obvious correlation between genetic structure and pelagic larval duration (PLD), reproductive strategy, 
TABle 4: Strength and direction of gene flow for Acanthurus nigroris: (1) between the MHI $(N=92$ individuals $)$, NWHI $(N=278$ individuals), and Johnston Atoll ( $N=34$ individuals), (2) among all remaining Pacific populations $(N=98)$, and (3) between Hawaiian and Pacific populations by pooling all sampled individuals (Hawaii, $N=445$; Pacific, $N=99$ ). Values are reported as the mean effective number of migrants $(\mathrm{Nm})$ per generation taken from ten independent runs.

\begin{tabular}{|c|c|c|c|c|}
\hline & \multicolumn{4}{|c|}{ Number of immigrants per generation into receiving population } \\
\hline & Comparison & $\begin{array}{c}2.5 \% \\
\text { percentile }\end{array}$ & Mean & $97.5 \%$ percentile \\
\hline \multirow{8}{*}{$\begin{array}{l}\text { Among regions } \\
\text { (Hawaii versus } \\
\text { Pacific) } \\
\text { Among } \\
\text { populations }{ }^{\mathrm{a}} \\
\text { (within Hawaii) }\end{array}$} & Hawaii into Pacific & 0 & 0.71 & 3.19 \\
\hline & Pacific into Hawaii & 0 & 0.34 & 1.63 \\
\hline & MHI into NWHI & 0 & 35.19 & 162.00 \\
\hline & NWHI into MHI & 0 & 22.99 & 132.00 \\
\hline & MHI into JOH & 0 & 3.69 & 26.04 \\
\hline & $\mathrm{JOH}$ into MHI & 4.79 & 62.11 & 197.00 \\
\hline & NWHI into JOH & 0 & 3.22 & 24.65 \\
\hline & JOH into NWHI & 3.83 & 62.56 & 190.00 \\
\hline \multirow{12}{*}{$\begin{array}{l}\text { Among } \\
\text { populations }{ }^{\mathrm{a}} \\
\text { (within Pacific) }\end{array}$} & AS into LI & 0 & 11.94 & 54.80 \\
\hline & AS into MI & 0 & 20.87 & 63.20 \\
\hline & AS into SI & 0 & 22.91 & 66.00 \\
\hline & LI into AS & 0 & 13.76 & 54.40 \\
\hline & MI into AS & 0 & 7.14 & 37.60 \\
\hline & SI into AS & 0 & 10.58 & 50.40 \\
\hline & LI into MI & 0 & 16.17 & 53.60 \\
\hline & LI into SI & 0 & 18.33 & 56.80 \\
\hline & MI into LI & 0 & 6.40 & 35.60 \\
\hline & SI into LI & 0 & 8.38 & 48.40 \\
\hline & MI into SI & 0 & 9.18 & 39.60 \\
\hline & SI into MI & 0 & 14.62 & 53.20 \\
\hline
\end{tabular}

AS: American Samoa; JOH: Johnston Atoll; LI: Line Islands; MHI: Main Hawaiian Islands; MI: Marshall Islands; NWHI: Northwest Hawaiian Islands; SI: Society Islands.

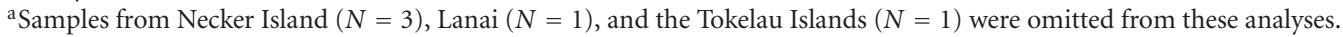

or habitat preference. Furthermore, there is no agreement among even closely related surgeonfish species with similar life-history characteristics. Indeed, one species (Ctenochaetus strigosus) shows genetic structure within Hawaii, whereas mtDNA of the other surgeonfish species considered, including A. nigroris, do not (Acanthurus nigrofuscus and Zebrasoma flavescens [38]; see [39]). Clearly connectivity between the MHI and NWHI needs to be evaluated on a case-bycase basis, incorporating the relevant facets of life history and ecology where possible (e.g., [86]); other factors not considered here (i.e., timing of reproduction, larval behavior, and ecological requirements) warrant further investigation. Indeed, several recent reports have drawn links between reef fish ecology and dispersal, phylogeography, and speciation [16, 86-89].

The estimates of gene flow generated here and elsewhere are useful in the design of marine reserves. Such gene flow estimates based on $F$ (or $\Phi$ ) statistics, however, are subject to several caveats [90]. Rare dispersal may be sufficient to ensure genetic homogeneity over evolutionary time scales, and so AMOVA analyses cannot distinguish whether genetic similarity among sampling sites is due to ongoing gene flow or incomplete lineage sorting (i.e., recent isolation).
In some cases, supplementation with physical tagging can solve this problem $[12,29]$, but such treatments are outside the scope of this study. We instead turn to Bayesian estimation of migration rates using coalescent procedures in MIGRATE [69], which clearly show elevated migration within the Hawaiian and Pacific regions in comparison to that between regions (Table 4). MIGRATE results also support an emerging trend for northwestward flow of larvae from the depleted reefs of the MHI into the healthy NWHI (i.e., existing MPA acts as a sink rather than a source; [91, 92]). Although MIGRATE-based estimates of gene flow based on a single molecular marker should be treated with caution, we are here interested in relative differences between regions and not absolute values. Therefore, these findings, along with complimentary data based on multi-disciplinary research in other taxa (e.g., genetics, mark-recapture, and oceanographic modeling), should be considered by managers in the design of future marine reserves in the MHI.

4.2. Johnston Atoll and the Colonization of Hawaii. Another objective in this study was to test for recent or ongoing genetic exchange between Hawaii and the rest of the Central Pacific. Indeed, the Hawaiian archipelago is separated from 
TABle 5: Surveys of intraspecific genetic structure $\left(\Phi_{S T}\right.$ or $\left.F_{S T}\right)$ in reef fishes sampled within the entire Hawaiian archipelago (i.e., Main Hawaiian Islands and Northwest Hawaiian Islands). Species common (and scientific) name, marker type (and mtDNA gene or number of nuclear loci), genetic structure, ecological differences (pelagic larval duration, PLD; Habitat type) between the study species, and references are listed here.

\begin{tabular}{|c|c|c|c|c|c|c|c|c|c|}
\hline Species & Marker type & $\begin{array}{l}\text { Genetic } \\
\text { structure? }\end{array}$ & $\begin{array}{l}\text { Genetic } \\
\text { break }\end{array}$ & $\begin{array}{c}\text { Global } \\
\text { (or pairwise) } \\
\Phi_{\mathrm{ST}} \text { or } F_{\mathrm{ST}}\end{array}$ & $\begin{array}{c}P \\
\text { value }\end{array}$ & $\begin{array}{l}\text { PLD } \\
\text { (days) }\end{array}$ & Reproduction & Habitat type & Reference \\
\hline $\begin{array}{l}\text { Bigscale soldierfish } \\
\text { (Myripristis berndti) }\end{array}$ & $\operatorname{mtDNA}($ Cyt $b)$ & No & $\mathrm{N} / \mathrm{a}$ & 0.00040 & $>0.05$ & 55 & $\mathrm{~N} / \mathrm{a}$ & $\begin{array}{l}\text { Subtidal reef } \\
\text { flats to outer } \\
\text { reef slopes }\end{array}$ & $\begin{array}{l}\text { Craig } \\
\text { et al. [36] }\end{array}$ \\
\hline $\begin{array}{l}\text { Blueline surgeonfish } \\
\text { (Acanthurus } \\
\text { nigroris) }\end{array}$ & mtDNA (Cyt $b)$ & No & $\mathrm{N} / \mathrm{a}$ & 0.011 & 0.073 & 55 to 60 & $\begin{array}{l}\text { Group, } \\
\text { broadcast } \\
\text { spawning }\end{array}$ & $\begin{array}{l}\text { Reef and } \\
\text { rubble (1 to } \\
90 \mathrm{~m})\end{array}$ & This study \\
\hline $\begin{array}{l}\text { Blue-striped } \\
\text { butterflyfish } \\
\text { (Chaetodon fremblii) }\end{array}$ & $\operatorname{mtDNA}$ (Cyt $b$ ) & No & $\mathrm{N} / \mathrm{a}$ & -0.014 & 0.41 & $\mathrm{~N} / \mathrm{a}$ & $\begin{array}{c}\text { Pair, } \\
\text { broadcast } \\
\text { spawning }\end{array}$ & Shallow reef & $\begin{array}{c}\text { Craig } \\
\text { et al. [37] }\end{array}$ \\
\hline $\begin{array}{l}\text { Brown surgeonfish } \\
\text { (Acanthurus } \\
\text { nigrofuscus) }\end{array}$ & $\operatorname{mtDNA}$ (Cyt $b$ ) & No & $\mathrm{N} / \mathrm{a}$ & -0.0060 & $>0.05$ & 55 to 60 & $\begin{array}{l}\text { Broadcast } \\
\text { spawning }\end{array}$ & $\begin{array}{l}\text { Reef and } \\
\text { rubble }\end{array}$ & $\begin{array}{l}\text { Eble et al. } \\
\quad[38]\end{array}$ \\
\hline $\begin{array}{l}\text { Hawaiian gregory } \\
\text { (Stegastes } \\
\text { fasciolatus) }\end{array}$ & Allozymes (8) & No & $\mathrm{N} / \mathrm{a}$ & 0.0010 to 0.0050 & $\mathrm{~N} / \mathrm{a}$ & 25 & $\begin{array}{l}\text { Demersal } \\
\text { eggs }\end{array}$ & $\begin{array}{l}\text { Reef and } \\
\text { rock }\end{array}$ & $\begin{array}{l}\text { Shaklee } \\
\text { and } \\
\text { Samollow } \\
{[129]}\end{array}$ \\
\hline $\begin{array}{l}\text { Hawaiian gregory } \\
\text { (Stegastes } \\
\text { fasciolatus) }\end{array}$ & $\begin{array}{l}\text { mtDNA } \\
\text { (control) }\end{array}$ & Yes & $\begin{array}{l}\text { NWHI } \\
\text { versus } \\
\text { MHI }\end{array}$ & 0.093 to 0.10 & $<0.05$ & 25 & $\begin{array}{l}\text { Demersal } \\
\text { eggs }\end{array}$ & $\begin{array}{l}\text { Reef and } \\
\text { rock }\end{array}$ & $\begin{array}{l}\text { Ramon } \\
\text { et al. [130] }\end{array}$ \\
\hline $\begin{array}{l}\text { Hawaiian grouper } \\
\text { (Epinephelus } \\
\text { quernus) }\end{array}$ & $\begin{array}{l}\text { mtDNA } \\
\text { (control) }\end{array}$ & Yes & $\begin{array}{l}\text { NWHI } \\
\text { versus } \\
\text { MHI }\end{array}$ & -0.007 to 0.043 & 0.01 & 40 & $\begin{array}{l}\text { Group, } \\
\text { broadcast } \\
\text { spawning }\end{array}$ & $\begin{array}{l}\text { Reef and } \\
\text { rubble }\end{array}$ & $\begin{array}{c}\text { Rivera } \\
\text { et al. [131] }\end{array}$ \\
\hline $\begin{array}{l}\text { Milletseed } \\
\text { butterflyfish } \\
\text { (Chaetodon miliaris) }\end{array}$ & $\operatorname{mtDNA}$ (Cyt $b$ ) & No & $\mathrm{N} / \mathrm{a}$ & -0.0050 & 0.66 & $\mathrm{~N} / \mathrm{a}$ & $\begin{array}{l}\text { Group, } \\
\text { broadcast } \\
\text { spawning }\end{array}$ & Shallow reef & $\begin{array}{l}\text { Craig et al. } \\
\quad[37]\end{array}$ \\
\hline $\begin{array}{l}\text { Milkfish (Chanos } \\
\text { chanos) }\end{array}$ & Allozymes (9) & Yes & $\begin{array}{c}\text { Oahu } \\
\text { versus } \\
\text { Hawaii }\end{array}$ & $\begin{array}{c}0.000080 \text { to } \\
0.0041\end{array}$ & $\mathrm{~N} / \mathrm{a}$ & 14 to 21 & $\begin{array}{l}\text { Group, } \\
\text { broadcast } \\
\text { spawning }\end{array}$ & $\begin{array}{l}\text { Shallow } \\
\text { reef/ } \\
\text { estuarine } \\
\text { (1 to } 30 \mathrm{~m})\end{array}$ & Winans [87] \\
\hline $\begin{array}{l}\text { Pebbled butterflyfish } \\
\text { (Chaetodon } \\
\text { multicinctus) }\end{array}$ & mtDNA (Cyt $b)$ & No & $\mathrm{N} / \mathrm{a}$ & -0.0080 & 0.82 & $\mathrm{~N} / \mathrm{a}$ & $\begin{array}{l}\text { Pair, } \\
\text { broadcast } \\
\text { spawning }\end{array}$ & Shallow reef & $\begin{array}{c}\text { Craig et al. } \\
\quad[37]\end{array}$ \\
\hline $\begin{array}{l}\text { Pink snapper } \\
\text { (Pristipomoides } \\
\text { filamentosus) }\end{array}$ & Allozymes (5) & No & $\mathrm{N} / \mathrm{a}$ & 0.0010 to 0.011 & $\mathrm{~N} / \mathrm{a}$ & $\begin{array}{c}60 \text { to } \\
120\end{array}$ & $\begin{array}{l}\text { Group, } \\
\text { broadcast } \\
\text { spawning }\end{array}$ & $\begin{array}{l}\text { Reef and } \\
\text { rock }(180 \text { to } \\
270 \mathrm{~m})\end{array}$ & $\begin{array}{c}\text { Shaklee } \\
\text { and } \\
\text { Samollow } \\
{[129]}\end{array}$ \\
\hline $\begin{array}{l}\text { Spotted surgeonfish } \\
\text { (Ctenochaetus } \\
\text { strigosus) }\end{array}$ & mtDNA (Cyt $b$ ) & Yes & $\begin{array}{c}\mathrm{P} \text { and } \mathrm{H} \\
\text { and } \\
\text { Maro } \\
\text { versus } \\
\text { rest } \\
\text { of islands }\end{array}$ & 0.034 to 0.074 & $\begin{array}{l}0.041 \\
\text { to } \\
0.008\end{array}$ & 55 to 60 & $\begin{array}{l}\text { Group/pair, } \\
\text { broadcast } \\
\text { spawning }\end{array}$ & Shallow reef & $\begin{array}{l}\text { Eble et al. } \\
\quad[38]\end{array}$ \\
\hline $\begin{array}{l}\text { Undulated moray } \\
\text { (Gymnothorax } \\
\text { undulatus) }\end{array}$ & $\begin{array}{l}\text { mtDNA (Cyt } b \\
\text { and COI) }\end{array}$ & Yes & $\begin{array}{c}\text { Maro } \\
\text { versus } \\
\text { Hawaii } \\
\text { and } \\
\text { Oahu }\end{array}$ & 0.060 to 0.10 & $<0.05$ & $\begin{array}{l}\text { Up to } \\
730\end{array}$ & Pair mating & $\begin{array}{l}\text { Reef and } \\
\text { rock }(1 \text { to } \\
100 \mathrm{~m})\end{array}$ & $\begin{array}{c}\text { Reece } \\
\text { et al. }[88]\end{array}$ \\
\hline $\begin{array}{l}\text { White-spotted } \\
\text { damselfish } \\
\text { (Dascyllus albisella) }\end{array}$ & $\begin{array}{l}\text { mtDNA } \\
\text { (control) }\end{array}$ & Yes & $\begin{array}{l}\text { NWHI } \\
\text { versus } \\
\text { MHI }\end{array}$ & 0.033 to 0.72 & $<0.05$ & 27 & $\begin{array}{l}\text { Pair, } \\
\text { broadcast } \\
\text { spawning }\end{array}$ & Shallow reef & $\begin{array}{l}\text { Ramon } \\
\text { et al. [130] }\end{array}$ \\
\hline
\end{tabular}


TABle 5: Continued.

\begin{tabular}{|c|c|c|c|c|c|c|c|c|c|}
\hline Species & Marker type & $\begin{array}{c}\text { Genetic } \\
\text { structure? }\end{array}$ & $\begin{array}{l}\text { Genetic } \\
\text { break }\end{array}$ & $\begin{array}{c}\text { Global } \\
\text { (or pairwise) } \\
\Phi_{\mathrm{ST}} \text { or } F_{\mathrm{ST}} \\
\end{array}$ & $\begin{array}{c}P \\
\text { value }\end{array}$ & $\begin{array}{l}\text { PLD } \\
\text { (days) }\end{array}$ & Reproduction & Habitat type & Reference \\
\hline $\begin{array}{l}\text { Yellow-edged moray } \\
\text { (Gymnothorax } \\
\text { flavimarginatus) }\end{array}$ & $\begin{array}{l}\text { mtDNA (Cyt } b \\
\text { and COI) }\end{array}$ & No & $\mathrm{N} / \mathrm{a}$ & -0.070 to 0.030 & $>0.05$ & $\begin{array}{l}\text { Up to } \\
730\end{array}$ & Pair mating & $\begin{array}{l}\text { Reef and } \\
\text { rock ( } 1 \text { to } \\
100 \mathrm{~m})\end{array}$ & $\begin{array}{c}\text { Reece et al. } \\
{[88]}\end{array}$ \\
\hline $\begin{array}{l}\text { Yellow tang } \\
\text { (Zebrasoma } \\
\text { flavescens) }\end{array}$ & mtDNA (Cyt $b$ ) & Yes & Hawaii & 0.077 to 0.17 & $\begin{array}{l}0.034 \\
\text { to } \\
0.001\end{array}$ & 55 to 60 & $\begin{array}{l}\text { Group, } \\
\text { broadcast } \\
\text { spawning }\end{array}$ & $\begin{array}{l}\text { Reef and } \\
\text { rubble (1 to } \\
\quad 80 \mathrm{~m})\end{array}$ & $\begin{array}{l}\text { Eble et al. } \\
\quad[38]\end{array}$ \\
\hline $\begin{array}{l}\text { Yellow tang } \\
\text { (Zebrasoma } \\
\text { flavescens) }\end{array}$ & $\begin{array}{l}\text { Microsatellite } \\
\text { (14) }\end{array}$ & Yes & Multiple & -0.010 to 0.042 & $\begin{array}{c}< \\
0.001\end{array}$ & 55 to 60 & $\begin{array}{l}\text { Group, } \\
\text { broadcast } \\
\text { spawning }\end{array}$ & $\begin{array}{l}\text { Reef and } \\
\text { rubble (1 to } \\
\quad 80 \mathrm{~m})\end{array}$ & $\begin{array}{c}\text { Eble et al. } \\
{[132]}\end{array}$ \\
\hline
\end{tabular}

Abbreviations: MHI: Main Hawaiian Islands; NWHI: Northwest Hawaiian Islands; P and H: Pearl and Hermes Reef.

other Central Pacific archipelagos by a minimum deep water gap of $c a .1400 \mathrm{~km}$. The Line Islands directly south of Hawaii represent the closest archipelago, and so this island chain has been suggested as a source of colonizing fishes. Gosline [63] proposed that at low sea level stands associated with glaciations periods, the North Equatorial Current (and Countercurrent) may have been deflected by the Line Islands, providing greater opportunities for colonization into Hawaii. Johnston Atoll has also been forwarded as a key gateway (i.e., stepping stone) for larvae dispersing into Hawaii given its intermediate location (minimum distance of $865 \mathrm{~km}$ ) and east/west prevailing current system $[63,93]$. In support of this possibility, our MIGRATE analysis indicates an order of magnitude greater gene flow from Johnston to Hawaii, rather than in the opposite direction (Table 4). Subtle (but overlapping) meristic differences between fish collected from Johnston versus all Hawaiian locations [48], however, along with concordant population-level isolation observed in this study, indicate that Johnston may simply serve as the southernmost outpost of Hawaiian A. nigroris [94]. Indeed, Johnston is genetically divergent from most (i.e., 9 out of 12 comparisons significantly different; pairwise $\Phi_{\mathrm{ST}}$ range: 0.043 to 0.19 ) but not all Hawaiian sampling sites (pairwise $\Phi_{\text {ST }}$ range: 0.0055 to 0.029 ).

The transport of larval fishes from the West Pacific via the Kuroshio extension of the North Pacific Equatorial Current has also been suggested as an alternative dispersal corridor into Hawaii $[94,95]$. This possibility is supported by the discovery of some West Pacific fishes in the NWHI, including the Japanese angelfish (Centropyge interruptus; [96, 97]) and the splendid perch (Grammatonotus macrophthalmus; [98]). Indeed, 4.6\% (57 species) of the Hawaiian fish fauna have ranges restricted to the Western North Pacific and Hawaiian Islands [98]. Using phylogenetic methods, Craig et al. [37] also showed that two endemic Hawaiian butterflyfish (Chaetodon fremblii and Chaetodon miliaris) groups with ancestral species in the West Pacific. We feel that this alternative colonization pathway is unlikely for A. nigroris, however, because this species is absent from the Pacific region west of Micronesia (i.e., China, Indonesia, Japan, Philippines, and Taiwan). Hence a South Pacific origin, as proposed by Gosline [63], seems more likely in this case.
That said, our analysis is based on extant populations only, with the observed phylogenetic separation of Hawaiian and Pacific fish being too old to provide clues; the conclusion of a southern colonization pathway into Hawaii must therefore be regarded as provisional.

4.3. Endemism in Hawaii. The possibility of an endemic surgeonfish species in Hawaii is not surprising given that this Pacific archipelago supports many endemic reef fishes (25\%; [31]). Although nuclear loci were not considered here, high levels of mtDNA differentiation between Hawaiian and Pacific A. nigroris (Table 2) is concordant with differences in morphology. More than half a century ago, Randall [48] noted variation in dorsal fin rays (Hawaii, range $=23$ to 26; Pacific, range $=24$ to 27 ) and anal soft rays (Hawaii, range $=22$ to 24 ; Pacific, range $=22$ to 25 ), as well as nonoverlapping gill raker counts (Hawaii, range $=26$ to 31 ; Pacific, range $=21$ to 25 ) between regions, although this morphological difference was not used to distinguish species at that time due to identical coloration. With the new genetic information provided here, a reclassification of this species is proposed in a companion paper, which includes a Hawaiian endemic (A. nigroris) and a widespread Pacific form (resurrected A. nigros; [99]). Given that other members of the genus Acanthurus show no genetic differentiation between Hawaii and elsewhere in the Pacific [39], what then might explain the apparent isolation of $A$. nigroris?

Several factors may contribute to the generation of endemic shore fishes. One conventional possibility is allopatric speciation, in this case by marine barriers that differentially impact larval dispersal [100]. Larvae must travel vast distances to either colonize or disperse outside the Hawaiian archipelago [94]. While some species may readily overcome these large stretches of open ocean, rare colonization events by a few individuals, coupled with natural selection (i.e., local adaptation, which may inhibit further gene flow; [101]) or the genetic consequences of variance in reproductive success (sweepstakes recruitment; [102]), could prompt rapid speciation [103]. Mesoscale eddy formation, upwelling zones, and sustained wind patterns may then enhance the local retention of fish larvae at oceanic islands and thus promote isolation between incipient species. 
Several studies have highlighted the genetic distinctiveness of Hawaiian fishes relative to other locations in the Pacific Ocean ([104-107] but see [39]). This is in contrast to reef fish populations within the Hawaiian archipelago that exchange propagules across the relatively short distances between neighboring reefs. High genetic connectivity between adjacent reefs may also explain the lack of adaptive radiation among Hawaiian fishes [108]. For example, few closely related marine species (i.e., sister taxa) cooccur in Hawaii $[109,110]$, and so most Hawaiian endemics are paired with widespread Indo-Pacific taxa in phylogenetic analyses (e.g., [37]).

The alternative hypothesis of speciation along ecological boundaries has been applied to explain the extremely high biodiversity on coral reefs $[16,82,111]$. While natural selection for habitat preference and other life-history traits is undoubtedly influencing the evolutionary pathways of Hawaiian fauna, we feel that ecological components are probably not driving speciation within A. nigroris. The evidence from comparisons of Johnston Atoll and Hawaiian locations indicate that 865 kilometers is near the limit of larval dispersal for this species. Indeed, the closest Hawaiian island, French Frigate Shoals, shares two common haplotypes with Johnston and is not genetically different, a pattern also apparent in other reef fishes [100]. The nearest alternate sites for dispersal and colonization are found in the Northern Line Islands (Kingman Reef and Palmyra Atoll), a minimal distance of $1385 \mathrm{~km}$ (see [93]). That said, our sample of A. nigroris from the Line Islands has been isolated from the Hawaiian population for approximately 2 my based on conventional mutation rates. Although divergence time estimates from single-locus data should be interpreted with caution (see [112]), our approximation is consistent with phylogenetic studies of closely related reef fishes that diverged in the last one to five million years (e.g., [113]). Our approximation is also consistent with the emerging trend for most Hawaiian marine biota to be much younger than the formation of the Hawaiian archipelago itself [35, 37]. Thus, the observed genetic pattern for A. nigroris in Hawaii likely reflects a long history of rare colonization and peripatric isolation resulting in divergence from ancestral Pacific populations.

Regardless of the process that generates endemic species, there are many unrecognized reef fishes awaiting discovery. As we have shown here, genetic tools are instrumental in identifying unique evolutionary significant units (ESUs, sensu [114]), which provide a phylogenetic framework for specifying taxa with highly restricted gene flow at the level of the species. Genetic methods have uncovered cryptic evolutionary lineages in other reef fish families in Hawaii (Canthigaster coronata, [115]; Cirrhitops fasciatus, [116]; Halichoeres ornatissimus, [117]), in addition to elsewhere in the Indo-Pacific (Discotrema monogrammum and Discotrema chrinophylum, [118]; Amphiprion melanopus, Cirrhilabrus punctatus, Labroides dimidiatus, and Pomacentrus moluccensis, [119]; Chaetodontoplus poliourus, [120]; Pictichromis dinar, [121]; Scarus ghobban, [122]) and Eastern Pacific (Epinephelus quinquefasciatus, [123]). In the tropical Atlantic Ocean, 8 out of 15 surveyed reef fishes showed cryptic evolutionary partitions [124]. Cryptic species are aptly named because they often develop barriers to fertilization despite a lack of accompanying divergence in other aspects of morphology or ecology (for review see [125]). This therefore stresses the importance of conducting range-wide genetic surveys for existing species to identify marine biodiversity that may have been overlooked (e.g., [126]).

In conclusion, we identified genetic isolation and independent evolutionary trajectories of Hawaiian and Pacific $A$. nigroris, despite high connectivity within each region. The Pacific Blueline Surgeonfish can readily traverse the tens to hundreds of kilometers between reef habitats in the Hawaiian Archipelago (average distance $=150$ kilometers) and the hundreds of kilometers between reef habitats elsewhere in the Pacific (maximum distance $=800$ kilometers; [127]). This species appears to rarely disperse between Johnston Atoll and the Hawaiian Archipelago (average distance $=1250$ kilometers), and there is effectively no migration between the Hawaiian Islands and other locations in the Pacific that are ca. $1400 \mathrm{~km}$ away or more (i.e., Line Islands). While such dispersal is impressive (and daunting from a management perspective), several other groups of reef fishes can even exceed this, including pygmy angelfishes (genus Centropyge; [127]), unicornfishes (genus Naso; [7]), soldierfishes (genus Myripristis; [36]), and moray eels (genus Gymnothorax; [88]). The Pacific BlueLine Surgeonfish therefore joins a growing list of reef fishes (Table 5) for which high dispersal is coupled with broad habitat and feeding preferences, as well as a large geographic range. These dispersive species present a special challenge to wildlife managers because they exhibit connectivity on a scale that far exceeds the boundaries of any single jurisdiction. We suggest that genetic connectivity in the less dispersive corals and other reef architects may provide guidelines for regional ecosystem-level management [128], but the more dispersive reef fishes demonstrate the need for international cooperation.

\section{Acknowledgments}

This research was supported by the National Science Foundation Grants OCE-0453167 and OCE-0929031 to B. W. Bowen, as well as NOAA National Marine Sanctuaries Program MOA no. 2005-008/66882. It was also funded in part by a Natural Sciences and Engineering Research Council of Canada (NSERC) postgraduate fellowship to J. D. DiBattista. The views expressed herein are those of the authors and do not necessarily reflect the views of these agencies. For specimen collections, the authors thank Kim Andersen, Paul H. Barber, J. Howard Choat, G. Concepcion, Toby S. DalyEngel, Joshua A. Drew, John L. Earle, Kevin Flanagan, Michelle R. Gaither, Brian D. Greene, Matthew Iacchei, Stephen A. Karl, Randall K. Kosaki, Carl G. Meyer, Yannis P. Papastamatiou, David Pence, Richard Pyle, Joshua Reece, D. Ross Robertson, Laurie Sorensen, Jennifer K. Schultz, Derek Skillings, Derek Smith, Zoltan Szabo, Kim Tenggardjaja, Tonatiuh Trejo-Cantwell, Bill Walsh, Ivor Williams, Jill P. Zamzow, and the crew of the R. V. Hi'ialakai. The authors also thank Robert Toonen, Serges Planes, Ben Victor, Hawaii Department of Land and Natural Resources, the Coral Reef 
Research Foundation, and the Papahānaumokuākea Marine National Monument, US Fish and Wildlife Service, and members of the ToBo lab for logistic support; Jack Randall for providing photographs; Jeff Eble and three anonymous reviewers for useful comments on the paper; Amy Eggers, Rajesh Shrestha, Lauren Valentino, and Mindy Mizobe of the HIMB EPSCoR core facility for their assistance with DNA sequencing. This is contribution no. 1417 from the Hawai' $i$ Institute of Marine Biology and no. 8061 from the School of Ocean and Earth Science and Technology.

\section{References}

[1] L. A. Rocha, M. T. Craig, and B. W. Bowen, "Phylogeography and the conservation of coral reef fishes," Coral Reefs, vol. 26, no. 3, pp. 501-512, 2007.

[2] E. A. Treml, P. N. Halpin, D. L. Urban, and L. F. Pratson, "Modeling population connectivity by ocean currents, a graph-theoretic approach for marine conservation," Landscape Ecology, vol. 23, no. 1, pp. 19-36, 2008.

[3] R. K. Cowen, "Larval dispersal and marine population connectivity," Annual Review of Marine Science, vol. 1, pp. 443-466, 2009.

[4] J. A. H. Benzie, "Genetic structure of coral reef organisms: ghosts of dispersal past," American Zoologist, vol. 39, no. 1, pp. 131-145, 1999.

[5] B. W. Bowen, A. L. Bass, L. A. Rocha, W. S. Grant, and D. R. Robertson, "Phylogeography of the trumpetfishes (Aulostomus): ring species complex on a global scale," Evolution, vol. 55, no. 5, pp. 1029-1039, 2001.

[6] L. van Herwerden, J. Benzie, and C. Davies, "Microsatellite variation and population genetic structure of the red throat emperor on the Great Barrier Reef," Journal of Fish Biology, vol. 62, no. 5, pp. 987-999, 2003.

[7] J. B. Horne, L. van Herwerden, J. H. Choat, and D. R. Robertson, "High population connectivity across the IndoPacific: congruent lack of phylogeographic structure in three reef fish congeners," Molecular Phylogenetics and Evolution, vol. 49, no. 2, pp. 629-638, 2008.

[8] P. Saenz-Agudelo, G. P. Jones, S. R. Thorrold, and S. Planes, "Estimating connectivity in marine populations: an empirical evaluation of assignment tests and parentage analysis under different gene flow scenarios," Molecular Ecology, vol. 18, no. 8, pp. 1765-1776, 2009.

[9] M. R. Christie, D. W. Johnson, C. D. Stallings, and M. A. Hixon, "Self-recruitment and sweepsteakes reproduction amid extensive gene flow in a coral-reef fish," Molecular Ecology, vol. 19, no. 5, pp. 1042-1057, 2010.

[10] M. E. Hellberg, R. S. Burton, J. E. Neigel, and S. R. Palumbi, "Genetic assessment of connectivity among marine populations," Bulletin of Marine Science, vol. 70, no. 1, pp. 273-290, 2002.

[11] G. Bernardi, S. J. Holbrook, R. J. Schmitt, and N. L. Crane, "Genetic evidence for two distinct clades in a French Polynesian population of the coral reef three-spot damselfish Dascyllus trimaculatus," Marine Biology, vol. 143, no. 3, pp. 485-490, 2003.

[12] G. P. Jones, S. Planes, and S. R. Thorrold, "Coral reef fish larvae settle close to home," Current Biology, vol. 15, no. 14, pp. 1314-1318, 2005.
[13] S. Planes, G. P. Jones, and S. R. Thorrold, "Larval dispersal connects fish populations in a network of marine protected areas," Proceedings of the National Academy of Sciences of the United States of America, vol. 106, no. 14, pp. 5693-5697, 2009.

[14] R. K. Cowen, K. M. M. Lwiza, S. Sponaugle, C. B. Paris, and D. B. Olson, "Connectivity of marine populations: open or closed?" Science, vol. 287, no. 5454, pp. 857-859, 2000.

[15] M. S. Taylor and M. E. Hellberg, "Genetic evidence for local retention of pelagic larvae in a Caribbean reef fish," Science, vol. 299, no. 5603, pp. 107-109, 2003.

[16] L. A. Rocha, D. R. Robertson, J. Roman, and B. W. Bowen, "Ecological speciation in tropical reef fishes," Proceedings of the Royal Society B, vol. 272, no. 1563, pp. 573-579, 2005.

[17] B. P. Kinlan and S. D. Gaines, "Propagule dispersal in marine and terrestrial environments: a community perspective," Ecology, vol. 84, no. 8, pp. 2007-2020, 2003.

[18] W. O. McMillan and S. R. Palumbi, "Concordant evolutionary patterns among Indo-West Pacific Butterflyfishes," Proceedings of the Royal Society B, vol. 260, no. 1358, pp. 229236, 1995.

[19] C. White, K. A. Selkoe, J. Watson, D. A. Siegel, D. C. Zacherl, and R. J. Toonen, "Ocean currents help explain population genetic structure," Proceedings of the Royal Society B, vol. 277, no. 1688, pp. 1685-1694, 2010.

[20] G. R. Almany, M. L. Berumen, S. R. Thorrold, S. Planes, and G. P. Jones, "Local replenishment of coral reef fish populations in a marine reserve," Science, vol. 316, no. 5825, pp. 742-744, 2007.

[21] D. O. Conover, L. M. Clarke, S. B. Munch, and G. N. Wagner, "Spatial and temporal scales of adaptive divergence in marine fishes and the implications for conservation," Journal of Fish Biology, vol. 69, pp. 21-47, 2006.

[22] L. A. Rocha, A. L. Bass, D. R. Robertson, and B. W. Bowen, "Adult habitat preferences, larval dispersal, and the comparative phylogeography of three Atlantic surgeonfishes (Teleostei: Acanthuridae)," Molecular Ecology, vol. 11, no. 2, pp. 243-252, 2002.

[23] K. Weersing and R. J. Toonen, "Population genetics, larval dispersal, and connectivity in marine systems," Marine Ecology Progress Series, vol. 393, pp. 1-12, 2009.

[24] J. Felsenstein, "How can we infer geography and history from gene frequencies?" Journal of Theoretical Biology, vol. 96, no. 1, pp. 9-20, 1982.

[25] H. K. Voris, "Maps of Pleistocene sea levels in Southeast Asia: shorelines, river systems and time durations," Journal of Biogeography, vol. 27, no. 5, pp. 1153-1167, 2000.

[26] M. Siddall, E. J. Rohling, A. Almogi-Labin et al., "Sea-level fluctuations during the last glacial cycle," Nature, vol. 423, no. 6942, pp. 853-858, 2003.

[27] Y. Yokoyama, K. Lambeck, P. De Deckker, P. Johnston, and L. K. Fifield, "Timing of the Last Glacial Maximum from observed sea-level minima," Nature, vol. 406, no. 6797, pp. 713-716, 2000.

[28] J. C. Briggs, Marine Zoogeography, McGraw-Hill, New York, NY, USA, 1974.

[29] C. Mora and P. F. Sale, "Are populations of coral reef fish open or closed?” Trends in Ecology and Evolution, vol. 17, no. 9, pp. 422-428, 2002.

[30] C. Moritz, "Defining "evolutionarily significant units" for conservation," Trends in Ecology and Evolution, vol. 9, no. 10, pp. 373-375, 1994.

[31] J. E. Randall, Reef and Shore Fishes of the Hawaiian Islands, University of Hawaii Press, Honolulu, Hawaii, USA, 2007. 
[32] E. A. Kay, Little Worlds of the Pacific: An Essay on Pacific Basin Biogeography, University of Hawaii Press, Honolulu, Hawaii, USA, 1980.

[33] I. A. Abbott, Marine Red Algae of the Hawaiian Islands, Bishop Museum Press, Honolulu, Hawaii, USA, 1999.

[34] J. E. Randall and J. L. Earle, "Annotated checklist of the shore fishes of the Marquesas Islands," Occasional Papers Bishop Museum, vol. 66, pp. 1-39, 2000.

[35] J. P. Price and D. A. Clague, "How old is the Hawaiian biota? Geology and phylogeny suggest recent divergence," Proceedings of the Royal Society B, vol. 269, no. 1508, pp. 2429-2435, 2002.

[36] M. T. Craig, J. A. Eble, B. W. Bowen, and D. R. Robertson, "High genetic connectivity across the Indian and Pacific Oceans in the reef fish Myripristis berndti (Holocentridae)," Marine Ecology Progress Series, vol. 334, pp. 245-254, 2007.

[37] M. T. Craig, J. A. E. Eble, and B. W. Bowen, "Origins, ages, and population histories: comparative phylogeography of endemic Hawaiian butterflyfishes (genus Chaetodon)," Journal of Biogeography, vol. 37, no. 11, pp. 2125-2136, 2010.

[38] J. A. Eble, R. J. Toonen, and B. W. Bowen, "Endemism and dispersal: comparative phylogeography of three surgeonfishes across the Hawaiian Archipelago," Marine Biology, vol. 156, no. 4, pp. 689-698, 2009.

[39] J. A. Eble, L. A. Rocha, M. T. Craig, and B. W. Bowen, "Not all larvae stay close to home: long-distance dispersal in IndoPacific reef fishes with a focus on the Brown Surgeonfish (Acanthurus nigrofuscus)," Journal of Marine Biology. In press.

[40] A. M. Friedlander and E. E. DeMartini, "Contrasts in density, size, and biomass of reef fishes between the northwestern and the main Hawaiian islands: the effects of fishing down apex predators," Marine Ecology Progress Series, vol. 230, pp. 253264, 2002.

[41] C. M. Roberts, J. A. Bohnsack, F. Gell, J. P. Hawkins, and R. Goodridge, "Effects of marine reserves on adjacent fisheries," Science, vol. 294, no. 5548, pp. 1920-1923, 2001.

[42] T. P. Hughes, D. R. Bellwood, and S. R. Connolly, "Biodiversity hotspots, centres of endemicity, and the conservation of coral reefs," Ecology Letters, vol. 5, no. 6, pp. 775-784, 2002.

[43] R. F. Myers, Micronesian Reef Fishes, Coral Graphics, Barrigada, Guam, 1991.

[44] A. M. Hart and G. R. Russ, "Response of herbivorous fishes to crown-of-thorns starfish Acanthaster planci outbreaks. III. Age, growth, mortality and maturity indices of Acanthurus nigrofuscus," Marine Ecology Progress Series, vol. 136, no. 13, pp. 25-35, 1996.

[45] B. N. Tissot and L. E. Hallacher, "Effects of aquarium collectors on Coral Reef Fishes in Kona, Hawaii," Conservation Biology, vol. 17, no. 6, pp. 1759-1768, 2003.

[46] P. J. Doherty, S. Planes, and P. Mather, "Gene flow and larval duration in seven species of fish from the Great Barrier Reef," Ecology, vol. 76, no. 8, pp. 2373-2391, 1995.

[47] R. Fisher, J. M. Leis, D. L. Clark, and S. K. Wilson, "Critical swimming speeds of late-stage coral reef fish larvae: variation within species, among species and between locations," Marine Biology, vol. 147, no. 5, pp. 1201-1212, 2005.

[48] J. E. Randall, "A revision of the surgeon fish genus Acanthurus," Pacific Science, vol. 10, no. 2, pp. 159-235, 1956.

[49] N. D. Meeker, S. A. Hutchinson, L. Ho, and N. S. Trede, "Method for isolation of PCR-ready genomic DNA from zebrafish tissues," BioTechniques, vol. 43, no. 5, pp. 610-614, 2007.
[50] C. B. Song, T. J. Near, and L. M. Page, "Phylogenetic relations among percid fishes as inferred from mitochondrial cytochrome $b$ DNA sequence data.," Molecular Phylogenetics and Evolution, vol. 10, no. 3, pp. 343-353, 1998.

[51] P. Taberlet, A. Meyer, and J. Bouvert, "Unusually large mitochondrial variation in populations of the blue tit, Parus caeruleus," Molecular Ecology, vol. 1, pp. 27-36, 1992.

[52] A. J. Drummond, B. Ashton, M. Cheung et al., Geneious v4.8, 2009, http://www.geneious.com.

[53] D. Posada, "jModelTest: Phylogenetic Model Averaging," Molecular Biology and Evolution, vol. 25, no. 7, pp. 12531256, 2008.

[54] S. Guindon and O. Gascuel, "A simple, fast, and accurate algorithm to estimate large phylogenies by maximum likelihood," Systematic Biology, vol. 52, no. 5, pp. 696-704, 2003.

[55] K. Tamura and M. Nei, "Estimation of the number of nucleotide substitutions in the control region of mitochondrial DNA in humans and chimpanzees," Molecular Biology and Evolution, vol. 10, no. 3, pp. 512-526, 1993.

[56] R. Excoffier, L. G. Laval, and S. Schneider, "Arlequin ver. 3.0: an integrated software package for population genetics data analysis," Evolutionary Bioinformatics Online, vol. 1, pp. 4750, 2005.

[57] M. Nei, Molecular Evolutionary Genetics, Columbia University Press, New York, NY, USA, 1987.

[58] L. Excoffier, P. E. Smouse, and J. M. Quattro, "Analysis of molecular variance inferred from metric distances among DNA haplotypes: application to human mitochondrial DNA restriction data," Genetics, vol. 131, no. 2, pp. 479-491, 1992.

[59] Y. Benjamini and D. Yekutieli, "The control of the false discovery rate in multiple testing under dependency," Annals of Statistics, vol. 29, no. 4, pp. 1165-1188, 2001.

[60] I. Dupanloup, S. Schneider, and L. Excoffier, "A simulated annealing approach to define the genetic structure of populations," Molecular Ecology, vol. 11, no. 12, pp. 2571-2581, 2002.

[61] F. Tajima, "Statistical method for testing the neutral mutation hypothesis by DNA polymorphism," Genetics, vol. 123, no. 3 , pp. 585-595, 1989.

[62] Y.-X. Fu, "Statistical tests of neutrality of mutations against population growth, hitchhiking and background selection," Genetics, vol. 147, no. 2, pp. 915-925, 1997.

[63] W. A. Gosline, "The inshore fish fauna of Johnston Island, a central Pacific atoll," Pacific Science, vol. 9, pp. 442-480, 1955.

[64] H.-J. Bandelt, P. Forster, and A. Röhl, "Median-joining networks for inferring intraspecific phylogenies," Molecular Biology and Evolution, vol. 16, no. 1, pp. 37-48, 1999.

[65] S. Schneider and L. Excoffier, "Estimation of past demographic parameters from the distribution of pairwise differences when the mutation rates vary among sites: application to human mitochondrial DNA," Genetics, vol. 152, no. 3, pp. 1079-1089, 1999.

[66] A. R. Rogers and H. Harpending, "Population growth makes waves in the distribution of pairwise genetic differences," Molecular Biology and Evolution, vol. 9, no. 3, pp. 552-569, 1992.

[67] W. H. Li, "Distribution of nucleotide differences between two randomly chosen cistrons in a finite population," Genetics, vol. 85, no. 2, pp. 331-337, 1977.

[68] H. A. Lessios, "The great American schism: divergence of marine organisms after the rise of the Central american Isthmus," Annual Review of Ecology, Evolution, and Systematics, vol. 39, pp. 63-91, 2008. 
[69] P. Beerli and J. Felsenstein, "Maximum likelihood estimation of a migration matrix and effective population sizes in $n$ subpopulations by using a coalescent approach," Proceedings of the National Academy of Sciences of the United States of America, vol. 98, no. 8, pp. 4563-4568, 2001.

[70] J. Hey and R. Nielsen, "Integration within the Felsenstein equation for improved Markov chain Monte Carlo methods in population genetics," Proceedings of the National Academy of Sciences of the United States of America, vol. 104, no. 8, pp. 2785-2790, 2007.

[71] P. Beerli, "Estimation of the population scaled mutation rate from microsatellite data," Genetics, vol. 177, no. 3, pp. 19671968, 2007.

[72] P. Beerli, "Effect of unsampled populations on the estimation of population sizes and migration rates between sampled populations," Molecular Ecology, vol. 13, no. 4, pp. 827-836, 2004.

[73] A. RoyChoudhury and M. Stephens, "Fast and accurate estimation of the population-scaled mutation rate, $\theta$, from microsatellite genotype data," Genetics, vol. 176, no. 2, pp. 1363-1366, 2007.

[74] P. Beerli, "How to use Migrate or why are markov chain monte carlo programs difficult to use?" in Population Genetics for Animal Conservation, G. Bertorelle, M. W. Bruford, H. C. Hauffe, A. Rizzoli, and C. Vernesi, Eds., pp. 42-79, Cambridge University Press, Cambridge, UK, 2009.

[75] P. Beerli and J. Felsenstein, "Maximum-likelihood estimation of migration rates and effective population numbers in two populations using a coalescent approach," Genetics, vol. 152, no. 2, pp. 763-773, 1999.

[76] P. Beerli, "Migrate: documentation and program, part of lamarc, version 2.0," 2004, http://popgen.sc.fsu.edu/Migrate/ Migrate-n.html.

[77] W. S. Grant and B. W. Bowen, "Shallow population histories in deep evolutionary lineages of marine fishes: insights from sardines and anchovies and lessons for conservation," Journal of Heredity, vol. 89, no. 5, pp. 415-426, 1998.

[78] P. Beerli, "Comparison of Bayesian and maximum-likelihood inference of population genetic parameters," Bioinformatics, vol. 22, no. 3, pp. 341-345, 2006.

[79] D. R. Bellwood, L. van Herwerden, and N. Konow, "Evolution and biogeography of marine angelfishes," Molecular Phylogenetics and Evolution, vol. 33, no. 1, pp. 140-155, 2004.

[80] L. A. Rocha, "Mitochondrial DNA and color pattern variation in three western Atlantic Halichoeres (Labridae), with the revalidation of two species," Copeia, vol. 2004, no. 4, pp. 770-782, 2004.

[81] J. L. Fessler and M. W. Westneat, "Molecular phylogenetics of the butterflyfishes (Chaetodontidae): taxonomy and biogeography of a global coral reef fish family," Molecular Phylogenetics and Evolution, vol. 45, no. 1, pp. 50-68, 2007.

[82] L. A. Rocha, K. C. Lindeman, C. R. Rocha, and H. A. Lessios, "Historical biogeography and speciation in the reef fish genus Haemulon (Teleostei: Haemulidae)," Molecular Phylogenetics and Evolution, vol. 48, no. 3, pp. 918-928, 2008.

[83] I. D. Williams, W. J. Walsh, R. E. Schroeder, A. M. Friedlander, B. L. Richards, and K. A. Stamoulis, "Assessing the importance of fishing impacts on Hawaiian coral reef fish assemblages along regional-scale human population gradients," Environmental Conservation, vol. 35, no. 3, pp. 261-272, 2008.

[84] C. Stevenson, L. S. Katz, F. Micheli et al., "High apex predator biomass on remote Pacific islands," Coral Reefs, vol. 26, no. 1, pp. 47-51, 2007.
[85] S. A. Sandin, J. E. Smith, E. E. DeMartini et al., "Baselines and degradation of coral reefs in the Northern Line Islands," PLoS ONE, vol. 3, no. 2, Article ID e1548, 2008.

[86] E. C. Franklin, C. V. Brong, A. R. Dow, and M. T. Craig, "Length-weight and length-length relationships of three endemic butterflyfish species (Chaetodontidae) from coral reefs of the Northwestern Hawaiian Islands, USA," Journal of Applied Ichthyology, vol. 25, no. 5, pp. 616-617, 2009.

[87] G. A. Winans, "Geographic variation in the milkfish Chanos chanos. I Biochemical evidence," Evolution, vol. 34, no. 3, pp. 558-874, 1980.

[88] J. S. Reece, B. W. Bowen, K. Joshi, V. Goz, and A. F. Larson, "Phylogeography of two moray eels indicates high dispersal throughout the Indo-Pacific," Journal of Heredity, vol. 101, no. 4, pp. 391-402, 2010.

[89] J. H. Choat, "Phylogeography and reef fishes: bringing ecology back into the argument," Journal of Biogeography, vol. 33, no. 6, pp. 967-968, 2006.

[90] J. E. Neigel, "Is $\mathrm{F}_{S T}$ obsolete?" Conservation Genetics, vol. 3, no. 2, pp. 167-173, 2002.

[91] C. E. Bird, B. S. Holland, B. W. Bowen, and R. J. Toonen, "Contrasting phylogeography in three endemic Hawaiian limpets (Cellana spp.) with similar life histories," Molecular Ecology, vol. 16, no. 15, pp. 3173-3186, 2007.

[92] M. R. Christie, B. N. Tissot, M. A. Albins et al., "Larval connectivity in an effective network of marine protected areas," PLos ONE. In press.

[93] D. R. Kobayashi, "Colonization of the Hawaiian Archipelago via Johnston Atoll: a characterization of oceanographic transport corridors for pelagic larvae using computer simulation," Coral Reefs, vol. 25, no. 3, pp. 407-417, 2006.

[94] T. F. Hourigan and E. S. Reese, "Mid-ocean isolation and the evolution of Hawaiian reef fishes," Trends in Ecology and Evolution, vol. 2, no. 7, pp. 187-191, 1987.

[95] J. E. Randall, "Zoogeography of shore fishes of the IndoPacific region," Zoological Studies, vol. 37, no. 4, pp. 227-268, 1998.

[96] S. Ralston, "A new record of the Pomacanthid fish Centropyge interruptus from the Hawaiian islands," Japanese Journal of Ichthyology, vol. 27, no. 4, pp. 327-329, 1981.

[97] R. L. Pyle, "Rare and unusual marines: the Japanese pygmy angelfish Centropyge interruptus (Tanaka)," Freshwater and Marine Aquarium, vol. 13, no. 3, pp. 35-37, 1990.

[98] B. C. Mundy, Checklist of the Fishes of the Hawaiian Archipelago, Bishop Museum Press, Honolulu, Hawaii, USA, 2005.

[99] J. E. Randall, J. D. DiBattista, and C. Wilcox, "Acanthurus nigros Günther, a valid species of surgeonfish, distinct from the Hawaiian A. nigroris Valenciennes," Pacific Science. In press.

[100] M. Leray, R. Beldade, S. J. Holbrook, R. J. Schmitt, S. Planes, and G. Bernardi, "Allopatric divergence and speciation in coral reef fish: the three-spot dascyllus, Dascyllus trimaculatus, species complex," Evolution, vol. 64, no. 5, pp. 1218-1230, 2010.

[101] A. F. Brown, L. M. Kann, and D. M. Rand, "Gene flow versus local adaptation in the northern acorn barnacle, Semibalanus balanoides: insights from mitochondrial DNA variation," Evolution, vol. 55, no. 10, pp. 1972-1979, 2001.

[102] D. Hedgecock, "Does variance in reproductive success limit effective population sizes of marine organisms?" in Genetics and Evolution of Aquatic Organisms, A. R. Beaumont, Ed., pp. 122-134, Chapman \& Hall, London, UK, 1994. 
[103] K. C. Hsu, J. P. Chen, and K. T. Shao, "Molecular phylogeny of Chaetodon (Teleostei: Chaetodontidae) in the Indo-West Pacific: evolution in geminate species pairs and species groups," The Raffles Bulletin of Zoology, vol. 14, pp. 77-86, 2007.

[104] C. A. Stepien, J. E. Randall, and R. H. Rosenblatt, "Genetic and morphological divergence of a circumtropical complex of goatfishes: Mulloidichthys vanicolensis, $M$. dentatus, and $M$. martinicus," Pacific Science, vol. 48, pp. 44-56, 1994.

[105] G. Bernardi, S. J. Holbrook, and R. J. Schmitt, "Gene flow at three spatial scales in a coral reef fish, the three-spot dascyllus, Dascyllus trimaculatus," Marine Biology, vol. 138, no. 3, pp. 457-465, 2001.

[106] S. Planes and C. Fauvelot, "Isolation by distance and vicariance drive genetic structure of a coral reef fish in the Pacific Ocean," Evolution, vol. 56, no. 2, pp. 378-399, 2002.

[107] L. K. Bay, J. H. Choat, L. Van Herwerden, and D. R. Robertson, "High genetic diversities and complex genetic structure in an Indo-Pacific tropical reef fish (Chlorurus sordidus): evidence of an unstable evolutionary past?" Marine Biology, vol. 144, no. 4, pp. 757-767, 2004.

[108] E. A. Kay and S. R. Palumbi, "Endemism and evolution in Hawaiian marine invertebrates," Trends in Ecology and Evolution, vol. 2, no. 7, pp. 183-186, 1987.

[109] V. G. Springer, Pacific Plate Biogeography, With Special Reference to Shorefishes, Smithsonian Institution, Washington, DC, USA, 1982.

[110] J. E. Randall, "Zoogeographic analysis of the inshore Hawaiian fish fauna," in Marine and Coastal Biodiversity in the Tropical Island Pacific Region, Species Systematics and Information Management Priorities, J. E. Maragos, M. N. A. Peterson, L. G. Eldredge, J. E. Bardach, and H. F. Takeuchi, Eds., pp. 193-203, Bishop Museum Press, Honolulu, Hawaii, USA, 1995.

[111] K. D. Crow, H. Munehara, and G. Bernardi, "Sympatric speciation in a genus of marine reef fishes," Molecular Ecology, vol. 19, no. 10, pp. 2089-2105, 2010.

[112] S. V. Edwards, "Relevance of microevolutionary processes for higher level molecular systematic," in Avian Molecular Systematics and Evolution, D. P. Mindell, Ed., pp. 251-278, Academic Press, New York, NY, USA, 1997.

[113] M. A. McCartney, J. Acevedo, C. Heredia et al., "Genetic mosaic in a marine species flock," Molecular Ecology, vol. 12, no. 11, pp. 2963-2973, 2003.

[114] D. J. Fraser and L. Bernatchez, "Adaptive evolutionary conservation: towards a unified concept for defining conservation units," Molecular Ecology, vol. 10, no. 12, pp. 27412752, 2001.

[115] J. E. Randall, J. T. Williams, and L. A. Rocha, "The IndoPacific tetraodontid fish Canthigaster coronata, a complex of three species," Smithiana Bulletin, vol. 9, pp. 3-13, 2008.

[116] J. E. Randall and J. K. Schultz, "Cirrhitops mascarenensis, a new species of hawkfish from the Mascarene Islands, southwestern Indian Ocean," Smithiana Bulletin, vol. 9, pp. 15-20, 2008.

[117] J. E. Randall and L. A. Rocha, "Halichoeres claudia sp. nov., a new Indo-Pacific wrasse (Perciformes: Labridae), the fourth species of the H. ornatissimus complex," Zoological Studies, vol. 48, no. 5, pp. 709-718, 2009.

[118] M. T. Craig and J. E. Randall, "Two new species of the IndoPacific clingfish genus Discotrema (Gobiesocidae)," Copeia, vol. 2008, no. 1, pp. 68-74, 2008.
[119] J. Drew, G. R. Allen, L. Kaufman, and P. H. Barber, "Endemism and regional color and genetic differences in five putatively cosmopolitan reef fishes," Conservation Biology, vol. 22, no. 4, pp. 965-975, 2008.

[120] J. E. Randall and L. A. Rocha, "Chaetodontoplus poliourus, a new angelfish (Percirformes: Pomacanthidae) from the tropical western Pacific," Raffles Bulletin of Zoology, vol. 57, no. 2, pp. 511-520, 2009.

[121] J. E. Randall and J. K. Schultz, "Pictichromis dinar, a new dottyback (Perciformes: Pseudochromidae) from Indonesia," Aqua, vol. 15, no. 4, pp. 169-176, 2009.

[122] M. Bariche and G. Bernardi, "Lack of a genetic bottleneck in a recent Lessepsian bioinvader, the blue-barred parrotfish, Scarus ghobban," Molecular Phylogenetics and Evolution, vol. 53, no. 2, pp. 592-595, 2009.

[123] M. T. Craig, R. T. Graham, R. A. Torres et al., "How many species of goliath grouper are there? Cryptic genetic divergence in a threatened marine fish and the resurrection of a geopolitical species," Endangered Species Research, vol. 7, pp. 167-174, 2009.

[124] B. W. Bowen, A. L. Bass, A. Muss, J. Carlin, and D. R. Robertson, "Phylogeography of two Atlantic squirrelfishes (family Holocentridae): exploring links between pelagic larval duration and population connectivity," Marine Biology, vol. 149, no. 4, pp. 899-913, 2006.

[125] D. Bickford, D. J. Lohman, N. S. Sodhi et al., "Cryptic species as a window on diversity and conservation," Trends in Ecology and Evolution, vol. 22, no. 3, pp. 148-155, 2007.

[126] T. S. Zemlak, R. D. Ward, A. D. Connell, B. H. Holmes, and P. D. N. Hebert, "DNA barcoding reveals overlooked marine fishes," Molecular Ecology Resources, vol. 9, supplement 1, pp. 237-242, 2009.

[127] J. K. Schultz, R. L. Pyle, E. DeMartini, and B. W. Bowen, "Genetic connectivity among color morphs and Pacific archipelagos for the flame angelfish, Centropyge loriculus," Marine Biology, vol. 151, no. 1, pp. 167-175, 2007.

[128] R. J. Toonen, K. R. Andrews, I. Baums et al., "Defining boundaries for applying Ecosystem-based management: a multispecies case study of marine connectivity across the Hawaiian Archipelago," Journal of Marine Biology. In press.

[129] J. B. Shaklee and P. B. Samollow, "Genetic variation and population structure in a deepwater snapper, Pristipomoides filamentosus, in the Hawaiian Archipelago," Fishery Bulletin, vol. 82, no. 4, pp. 703-713, 1984.

[130] M. L. Ramon, P. A. Nelson, E. De Martini, W. J. Walsh, and G. Bernardi, "Phylogeography, historical demography, and the role of post-settlement ecology in two Hawaiian damselfish species," Marine Biology, vol. 153, no. 6, pp. 1207-1217, 2008.

[131] M. A. J. Rivera, C. D. Kelley, and G. K. Roderick, "Subthe population genetic structure in the Hawaiian grouper, Epinephelus quernus (Serranidae) as revealed by mitochondrial DNA analyses," Biological Journal of the Linnean Society, vol. 81, no. 3, pp. 449-468, 2004.

[132] J. A. Eble, R. J. Toonen, L. Sorenson, L. V. Basch, Y. P. Papastamatiou, and B. W. Bowen, "Phylogeography and historical demography of the Yellow Tang (Zebrasoma flavescens) indicate a Hawaiian origin for an Indo-Pacific reef fish," Marine Ecology Progress Series. In press. 

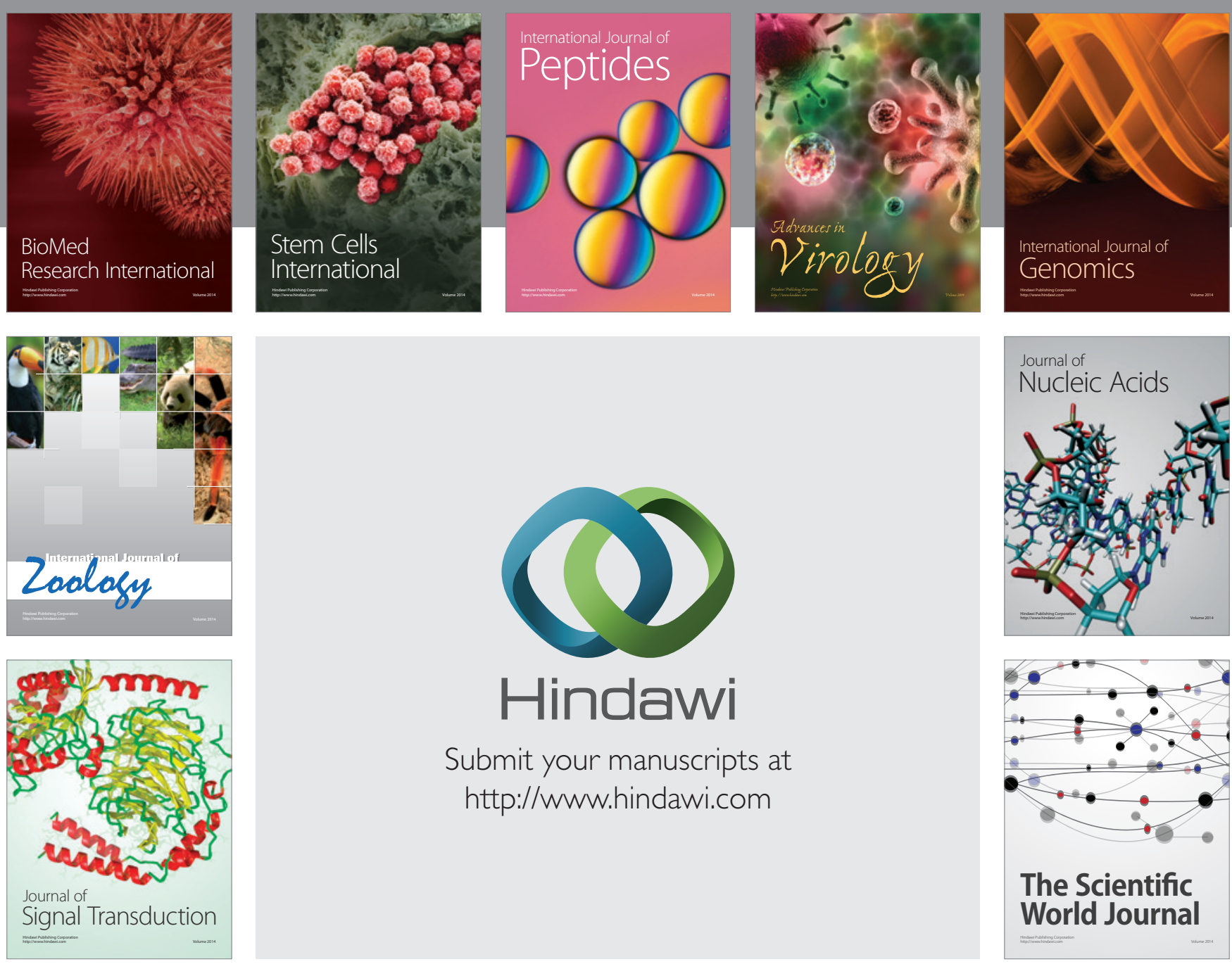

Submit your manuscripts at

http://www.hindawi.com
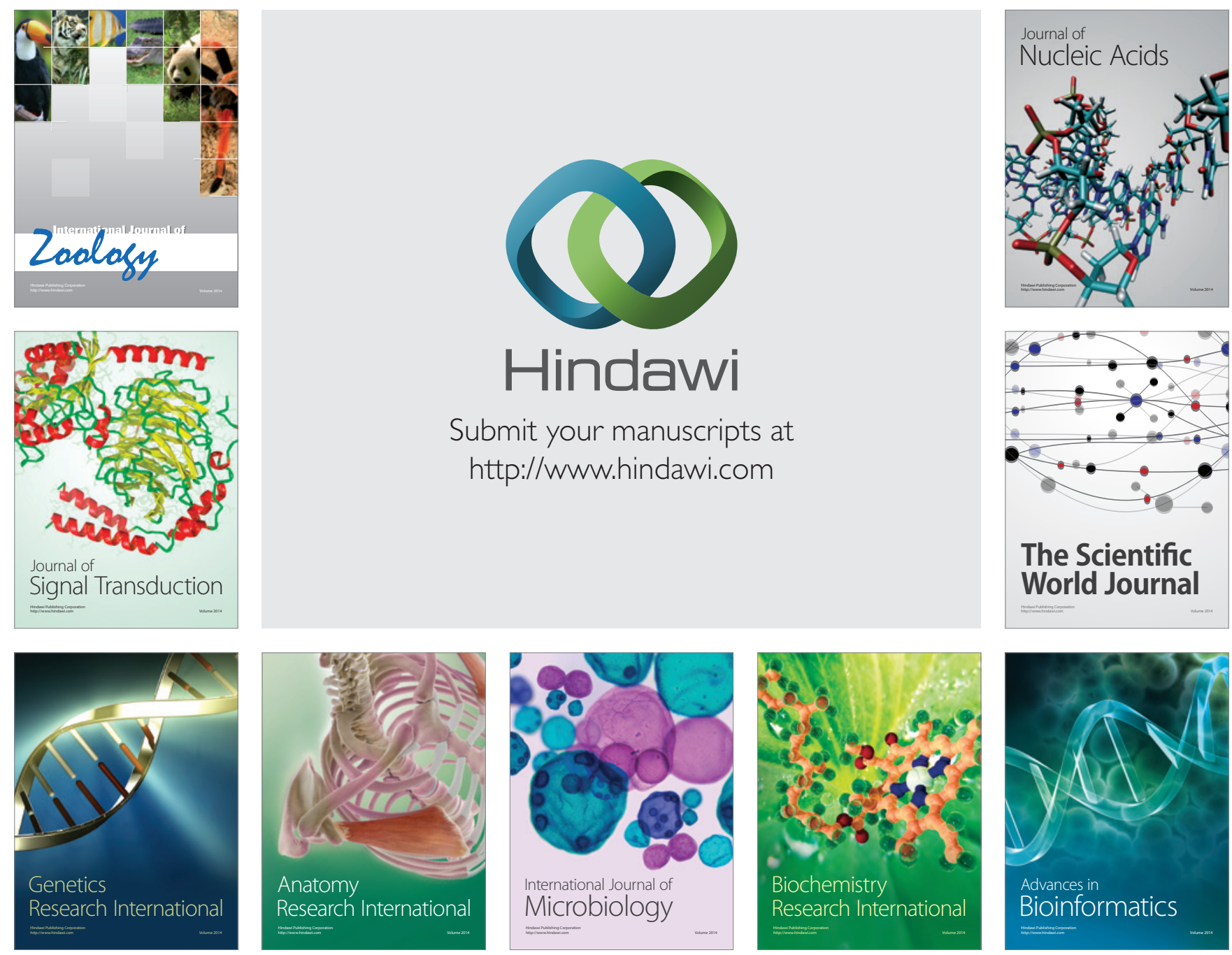

The Scientific World Journal
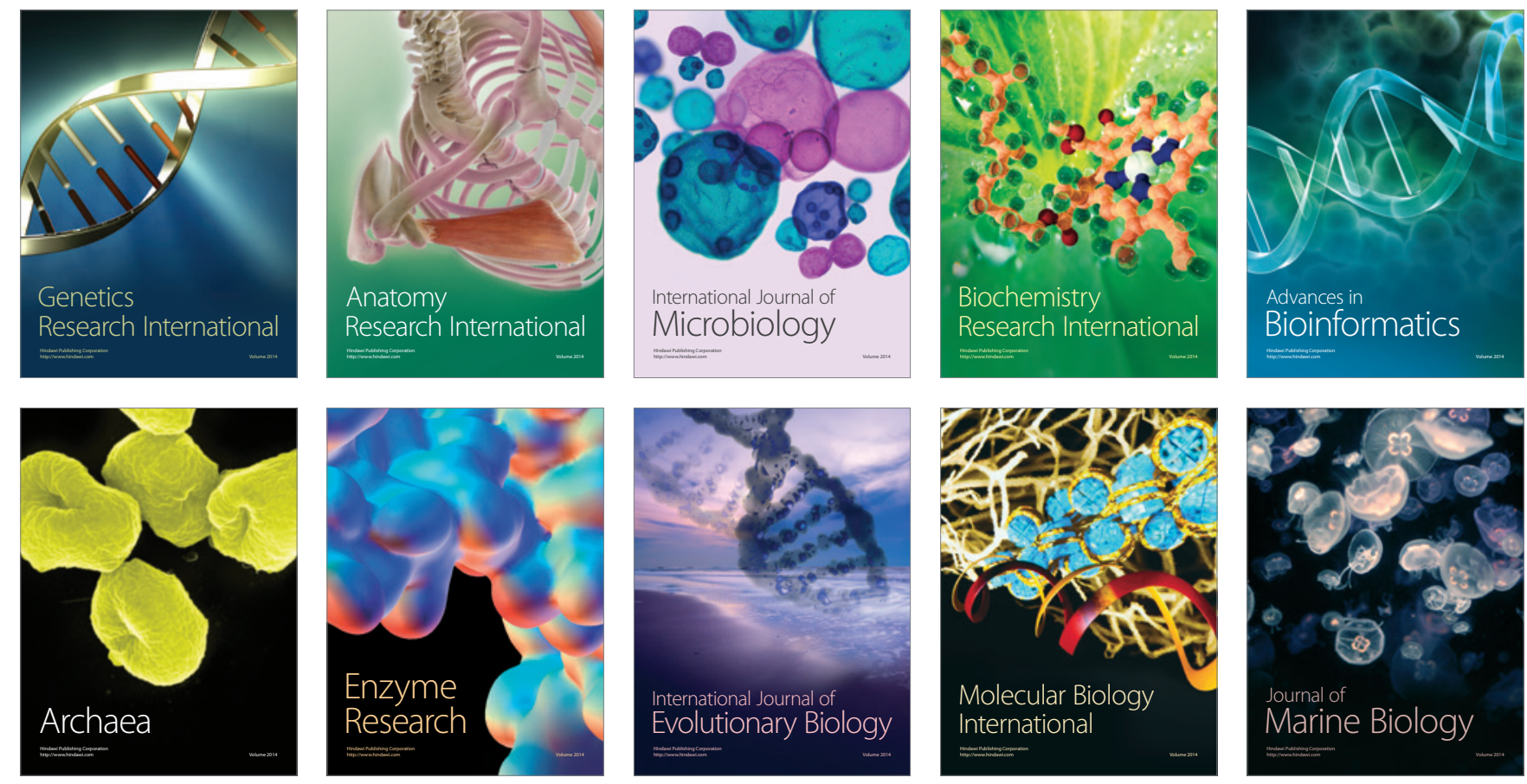